\title{
Potegavščine, miti in predsodki v znanosti: primer Pierra Trémauxa
}

\author{
Hoaxes, myths and prejudice in science: example of Pierre Trémaux
}

\section{Tvrtko-Matija Šercar ${ }^{1}$}

IZVLEČEK: Pregledovanje literature je neločljiv del raziskovalnega dela. Zgodba o Pierru Trémauxu (1818-1895) ponazarja, kako faktorji, kot so potegavščine, novinarske race, neresnične pripovedi, miti in predsodki, ki ne spadajo $v$ znanost, težave pri dojemanju in sprejemanju novih znanstvenih paradigem ter tudi počasno in geografsko omejeno širjenje znanstvenih spoznanj in posledično neinformiranost o znanstvenih odkritjih drugje po svetu, škodijo ekologiji znanstvenega komuniciranja in informiranja. Trémaux in njegovo delo sta znana le na osnovi dopisovanja med Karlom Marxom (1818-1883), ki je mislil, da je knjiga imenitna, in Friedrichom Engelsom (1820-1895), ki je menil, da je knjiga slaba. Trémauxa ni v nobeni standardni zgodovini biologije, čeprav je s svojim delom predvidel nekatere teorije, ki so jih kot svoje predstavili drugi. Tu gre predvsem za teorije prekinjenega ravnotežja, filogenetsko drevo, speciacijo in posledično vpliv na teorije ras. $Z$ metodološkega vidika naj bi bil glavni izsledek tega prikaza domneva, da so rasne teorije sofisticirano ideološko sredstvo za opravičevanje hegemonije, imperializma in kolonializma, nacionalizma in diskriminacije skupin in posameznikov ter drugih oblik krivičnega svetovnega reda med narodi, rasami in posamezniki $v$ preteklosti, sedanjosti in prihodnosti, $v$ smislu, da so nekatere nacije, rase in posamezniki boljši kot drugi, namesto da bi prispevale k pojasnjevanju razlik med njimi brez kakršnega koli vrednotenja.

KLJUČNE BESEDE: Pierre Trémaux (1818-1895), bibliografski pregled, teorije ras

ABSTRACT: The literature review is an integral part of research. The story of Pierre Trémaux (18181895) illustrates how factors, such as hoaxes, fabrications, untrue stories, myths and prejudice, which have nothing to do in science, difficulties in comprehending and accepting new scientific paradigms and also slow and geographically limited dissemination of scientific findings, which results in not being familiar with scientific findings and discoveries elsewhere in the world, are harmful for the ecology of scientific communication. Trémaux and his work are known only based on the correspondence between Karl Marx, who thought that Trémaux's book was excellent, and Friedrich Engels, who was of the opinion that the book was bad. Trémaux is not included in any standard history of biology although, with his work, he anticipated some theories that others presented as theirs. This primarily refers to theories of punctuated equilibrium, phylogenetic tree, speciation and, consequently, the impact on race theories. From the methodological aspect, the main result of this presentation is the assumption that race theories are a sophisticated ideological means to justify hegemony, imperialism and colonialism, nationalism and discrimination of groups and individuals and other forms of unjust world order between nations, races and individuals in the past, at present and in the future, in the sense that some nations, races and individuals are better than others instead of contributing to the explanation of the differences between them without any judgement.

KEYWORDS: Pierre Trémaux (1818-1895), bibliographic overview, race theories

Povod za nastanek članka je bila 200. obletnica rojstva Pierrea Trémauxa in Karla Marxa, ki sta se oba rodila leta 1818.

${ }^{1}$ Dr. Tvrtko-Matija Šercar, upokojeni sodelavec IZUM, tvrtko.sercar@ext.izum.si. 


\section{Uvodna opomba}

V članku Plaidoyer za prenovljeno teorijo informacij sem ugotovil, da je resnica temelj ekologije informacij. Iz napačnih podatkov ne moremo organizirati informacij, prav tako tudi ne znanja iz lažnih informacij (Šercar, 2012). Pregledovanje literature je obvezni del raziskovalnega dela. Resni znanstveniki, ki tega ne počnejo, so izjema, kot je bil angleški induktivni empirist Francis Bacon (1561-1626), ki ni cenil knjig, saj je treba »brati« naravo, in zato v svoji utopiji Nova Atlantida (2011) sploh ni predvidel knjižnice.

Prva izdaja Darwinove knjige $O$ izvoru vrst je bila natisnjena leta 1859, in to le v 1.250 izvodih, ki so bili vsi razprodani na dan objave. Eden od tistih, ki je dobil izvod, je bil Friedrich Engels, ki je tedaj živel v Manchestru. Tri tedne kasneje je pisal Karlu Marxu: „Darwin, mimogrede, ki ga pravkar berem, je absolutno čudovit. Obstajal je en vidik teleologije, ki še ni bil uničen, in to je zdaj storjeno. Nikoli prej ni bilo tako veličastnega poskusa, da bi prikazali zgodovinsko evolucijo v naravi in zagotovo nikoli s takšnim uspehom « (Marx in Engels, MECW, 1975).

Ko je Marx leto kasneje prebral knjigo $O$ izvoru vrst, je bil enako navdušen, saj gre za knjigo, ki vsebuje "osnovo za naš pogled na zgodovino narave». (Marx in Engels, MESC, 1975a). V pismu nemškemu socialistu Ferdinandu Lasalleju (1825-1864) je napisal, da je Darwinovo delo epohalno in da ustreza svojemu namenu, ker zagotavlja podlago $v$ naravoslovju za njegov zgodovinski materializem in razredni boj. Kljub vsem pomanjkljivostim se tu prvič teleologija $v$ naravoslovju ne obravnava samo kot smrtni udarec, pač pa je njen razumski pomen empirično pojasnjen (Marx in Engels, MECW, 1975b).

\section{Darwin in evolucionisti pred njim}

Pred Darwinom so o evoluciji pisali Georges-Louis Leclerc De Buffon (1707-1788), ded Charlesa Darwina Erasmus Darwin (1731-1802), Jean-Baptiste Lamarck (1744-1829) in Robert Chambers (1802-1871) (Angus, 2018). Georges-Louis Leclerc De Buffon je znan po obsežnem delu o zgodovini narave Histoire naturelle, générale et particulière, s katerim se je ukvarjal okoli 50 let in je prvi sodobni poskus sistematične predstavitve vseh obstoječih znanj s področij naravoslovja, geologije in antropologije v eni publikaciji. Čeprav je Charles Darwin v tretji izdaji svoje knjige $O$ izvoru vrst zapisal, da se ne strinja z Buffonom, pa je že v naslednji, četrti izdaji poudaril, da je Buffon prvi sodobni avtor, ki je evolucijo obravnaval v znanstvenem duhu.

Buffon je pisal o konceptu boja za preživetje. Razvil je sistem dednosti, ki je bil podoben Darwinovi sicer zgrešeni hipotezi o pangenezi, po kateri se $v$ vsaki celici organizma ustvarijo specifične celice, gemule, ki se zbirajo $v$ spolnih celicah, skozi katere se lastnosti prenesejo na potomce. Buffon in Johann Friedrich Blumenbach ${ }^{2}$ (1752-1840) sta bila prepričana o monogenezi, konceptu, da imajo vse rase en sam izvor. Prav tako sta verjela $v \mathrm{t}$. i. degenerativno hipotezo o rasnem izvoru, ki je zelo vplivala na razvoj rasističnih teorij. Adam in Eva sta predstavnika kavkaške rase, vse druge rase so posledica degeneracije, ki so jo povzročili okoljski dejavniki, kot sta sonce in slaba prehrana. Verjeli so, da so degenerativne

\footnotetext{
2 Johann Friedrich Blumenbach na splošno velja za ustanovitelja fizične in znanstvene antropologije. Prvi je uporabil besedo rasa (leta 1775) pri razvrstitvi ljudi v pet ras: kavkaško, mongolidno, etiopsko, ameriško in malajsko. Skoval je tudi izraz kavkaški, ker je verjel, da je kavkaška regija proizvedla najlepšo raso. Carl von Linné (1707-1778) in Blumenbach sta menila, da so ljudje ena vrsta. Blumenbach je tudi eden od ustanoviteljev primerjalne anatomije.
} 
spremembe pod ustreznim okoljskim nadzorom reverzibilne in da bi se vse sodobne oblike človeka lahko vrnile v prvotno kavkaško raso.

Ded Charlesa Darwina Erasmus Darwin je opisal nekaj podobnega evoluciji v svoji knjigi Zoonomia iz leta 1794 in ponovno leta 1803 v pesmi z naslovom The Temple of Nature (Tempelj narave). Njegove evolucijske ideje niso vplivale na nikogar, kar naj bi bila posledica velikega deleža ugibanj v odnosu do dejstev, kot je kasneje napisal Charles Darwin.

Lamarck je trdil, da so vse sodobne živali potomci manj kompleksnih prednikov. Za razliko od Darwina Lamarck ni predlagal skupnega porekla, ampak kompleksnejši model, v katerem je vsak tip organizma šel skozi ločen evolucijski proces. Narava nenehno in spontano ustvarja nove evolucijske linije, začenši z enoceličnimi živalmi, ki imajo naravni zagon, da postanejo sčasoma kompleksnejše ali popolne. Sčasoma, če se vzpon ne prekine, dosežejo vrhunec popolnosti kot človeška bitja. Toda vzpon pogosto prekinejo okoljske spremembe, na katere se mora žival odzvati. Žirafe razvijejo dolge vratove z raztezanjem, da dosežejo visoke liste, medtem ko ribe, ki živijo $v$ jamah, postanejo slepe, ker ne uporabljajo svojih oči - in te spremembe nato podedujejo njihovi potomci. V Lamarckovih delih je bil to sekundarni proces, toda izraz »lamarkizem« je od takrat pomenil »dedovanje pridobljenih lastnosti« in nič drugega.

V naravi obstaja počasen proces preoblikovanja vrst. Po zakonu kontinuitete Gottfrieda Wilhelma von Leibniza (1646-1716) »narava ne dela skokov« (lat. natura non saltum facit). Dejavniki tega procesa so spremembe okolja, ki vplivajo na spremembe potreb in navad živali. V skladu z novimi potrebami in navadami se nekateri organi bolj uporabljajo in razvijajo, drugi pa manj ter zakrnijo in izginejo pri potomcih. Pridobljene lastnosti se lahko podedujejo. Osnovno načelo evolucije je neki teleološki postulat, notranji namen. Spremembe so vedno primerne pogojem sredine, starši pa jih prenašajo na potomce. Čeprav so ti pogledi pridobili le malo podpore drugih znanstvenikov, tudi v Franciji, je v Angliji v obdobju med 1820 in 1850 med radikalnimi demokrati, socialisti in sekularisti obstajala Lamarckova struja, ki je lamarkovske argumente uporabila za kritiko nedemokratičnosti angleške države in anglikanske cerkve.

Veliko večji vpliv na široko javno mnenje $v$ Angliji je imelo delo Vestiges of the Natural History of Creation (Sledi naravne zgodovine ustvarjanja), ki ga je leta 1844 anonimno objavil Robert Chambers, založnik in amaterski geolog iz Edinburgha. Chambers je celotno zgodovino vesolja pripisal Božjemu zakonu razvoja, ki ustvarja zvezde, planete in na koncu življenje. Po prvem pojavu življenja, ki se je spontano pojavilo na Zemlji, so se živali in rastline povzpele po lestvi življenja. Božja previdnost je poskrbela, da ena vrsta rodi drugo, dokler se ni rodil tudi človek kot najvišja vrsta. Chambers je dobesedno mislil na rojstvo. To idejo so takratne znanstvene ustanove obsodile in je danes skoraj pozabljena, vendar je bila Chambersova knjiga edino delo o evoluciji, ki so ga lahko brali angleški bralci, preden je nastalo Darwinovo delo.

Znanstvena odkritja v poznem osemnajstem in zgodnjem devetnajstem stoletju so izzvala široke razprave o Herschlovi »skrivnosti vseh skrivnosti«. Večina znanstvenikov in mnogi amaterji so se ukvarjali s pojasnjevanjem izumrtja in ustvarjanja vrst. Ne glede na razlike so vse razlage temeljile na skupni ideologiji, bodisi esencializmu bodisi teleologiji.

Esencializem temelji na prvem zakonu formalne logike, da je stvar vedno enaka sebi, da je A vedno enako A. To je koristna, celo nujna predpostavka za mnoge namene, vendar zanemarja 
dejstvo, da stvari skozi čas razpadajo, se preoblikujejo in združujejo, tako da se A spremeni v nekaj, kar ni več A. V naravoslovju devetnajstega stoletja so esencialistični misleci domnevali, da je splošni pojem vrste pomembnejši in dejansko resničnejši od konkretnih organizmov, ki jih lahko neposredno opazujemo. Vrsta je konstanten, nespremenljiv tip, medtem ko so variacije, ki jih opazimo v naravi, naključne in prehodne. Tako je npr. William Whewell (17941866) trdno verjel, da imajo vrste resnično bivanje $v$ naravi in prehod iz ene $v$ drugo ne obstaja. Charles Lyell (1797-1875), takrat vodilni geolog, je zavračal evolucijo in posvetil več poglavij svoje najpomembnejše knjige Principles of geology (Načela geologije) kritiki Lamarcka in ideje, da se vrste lahko spremenijo. Po Stephenu Jayu Gouldu (1941-2002) (1999a) Lyellova teorija ne sloni na dejanskem proučevanju narave, ampak na esencialistični filozofiji. Vendar so tudi ljudje, kot je bil Chambers, ki so menili, da iz ene vrste nastane druga, spadali med esencialiste. Po njihovem razumevanju evolucije se vrste ne spreminjajo, temveč eno vrsto $v$ celoti nadomesti nova vrsta.

Teleologija je prepričanje, da so vsi pojavi smotrni in da ima vse dogajanje vnaprej določen namen. Ptice so dobile krila, da bi lahko letele, žirafe imajo dolge vratove, da bi lahko dosegle visoke liste, Zemlja pa je bila ustvarjena kot prostor za življenje ljudi. Idejo, da je Zemljo in vse na njej ustvaril Bog, da bi dosegel svoje božanske cilje, so v 19. stoletju sprejeli skoraj vsi vodilni filozofi in znanstveniki. Tudi resni misleci so bili prepričani, da so bila nahajališča premoga $v$ Angliji vnaprej določena, da bi jih kasneje lahko uporabila industrija; prav tako so bili prepričani, da je to, da je življenjski cikel rastlin enak trajanju kroženja Zemlje okrog Sonca, očiten primer Božje postave. Celo Lamarck, ki Boga sicer ni vključil v svojo teorijo, je trdil, da obstaja skrivnostna sila, ki vse organizme spodbuja, da postanejo vedno popolnejši, dokler ne dosežejo popolnosti človeških bitij.

Za razliko od Lamarcka in Chambersa Darwin ni špekuliral. Njegova teorija izvora z modifikacijo skozi naravno selekcijo je bila razvita in nato natančno oblikovana $v$ več letih skrbnega proučevanja in eksperimentiranja. V knjigi $O$ izvoru vrst je Darwin pokazal, da na ustvarjanje novih vrst delujejo naslednji trije dejavniki:

1. populacijski pritisk (Vsi organizmi imajo običajno več potomcev, kot jih lahko preživi v lokalnem okolju. Mnogi organizmi ne preživijo ali niso sposobni za razmnoževanje.);

2. variacije in dednost (Med člani določene populacije je veliko razlik - dva popolnoma enaka organizma ne obstajata. Večina teh variacij je dednih, prenašajo se na potomce. Medtem ko je večina teh sprememb nepomembna (na primer barva oči), nekatere lahko povečajo ali zmanjšajo možnosti organizma za preživetje in razmnoževanje.);

3. naravna selekcija (Organizmi z ugodnimi variacijami bodo imeli več potomcev, kot je povprečje, tisti z neugodnimi variacijami pa manj. Posledica tega je, da se bodo v daljšem časovnem obdobju neugodna odstopanja pogosto zmanjšala, medtem ko bodo ugodnejše spremembe postale pogostejše.).

To je pomenilo novo razlago dolgega vratu žirafe. V nasprotju z Lamarckom je Darwin dokazal, da so imeli predniki žirafe vratove različnih dolžin. Tisti z daljšimi vratovi so lahko dosegli več listov kot tisti s krajšimi vratovi. Ker so bili bolje nahranjeni, so bili močnejši, večinoma so živeli dlje in imeli več potomcev, tako da se je sčasoma povečala tudi povprečna dolžina vratu $v$ populaciji. 


\section{Zgodba o Pierru Trémauxu}

Zgodba o Pierru Trémauxu ponazarja, kako lahko neznanstvena dejstva, kot so potegavščne, novinarske race, neresnične pripovedi, miti in predsodki ter počasno in geografsko zelo omejeno širjenje znanstvenih spoznanj in posledično neinformiranost o znanstvenih odkritjih drugje po svetu, povzročijo nerazumevanje in neustrezne ocene prispevka k skokovitemu kumulativnemu razvoju naravoslovnih znanosti (humanistične znanosti so repetitivne) in škodijo ekologiji znanstvenega komuniciranja in informiranja. Diskontinuiteta je posledica sprememb med seboj izključujočih paradigem neznanega vzroka, saj igrajo srečna naključna odkritja in spoznanja po Mertonu in Barberjevi pomembno vlogo pri iskanju znanstvene resnice (Campa, 2008). Trémaux (1865) je uporabil prispodobo, da mu je sam Bog posredoval svojo skrivnost (Dieu va nous livrer son secret!, 136). Teologi temu rečejo božja previdnost, znanstveniki naključje (Stendhal, 1932).

Pierre Trémaux (1818-1895) je danes bolj znan kot francoski arhitekt, orientalist in fotograf zgornjega Nila in Sudana ter po geološko-antropoloških člankih s popotovanja po Sudanu, objavljenih med letoma 1849 in 1862 . Le malokdo je slišal za njegovo filogenetsko delo (Morrison, 2013), dokler nista leta 2008 avstralska biologa John S. Wilkins in Gareth J. Nelson objavila članka Trémaux on species: a theory of allopatric speciation (and punctuated equilibrium) before Wagner. Poleg Trémauxa in Moritza Wagnerja ter J. S. Wilkinsa in G. J. Nelsona so v naši zgodbi udeleženi tudi znanstveniki in misleci, kot so Charles Darwin, Karl Marx in Friedrich Engels ter Stephen Jay Gould.

Tako je leta 1866, sedem let po Darwinovi prvi izdaji $O$ izvoru vrst, Marx pisal Engelsu³ , da predstavlja objavljena Trémauxeva knjiga o evoluciji »zelo pomemben napredek $v$ primerjavi z Darwinom«. Engels, ki je veliko bolj pozorno spremljal novosti v znanosti kot Marx, mu je odgovoril, da Trémauxeva knjiga nima nobene vrednosti, povzeti sklepi pa so popolnoma zgrešeni, neverjetno enostranski in pretirani (MECW, vol. 42, 304, 320, 324).

Wilkins in Nelson (2008) sta pokazala, da si Trémaux zasluži ugled teoretičnega biologa. Njegova najbolj znana knjiga Origin et Transformations de l'Homme et des Autres Êtres iz leta 1865 (ponovno izdana leta 2013) obravnava izvor in transformacijo človeka in drugih bitij. Evolucionisti so uporabljali besedo transformacija, preden so jo kasneje zamenjali z besedo evolucija. Zamenjava je bila ponesrečena, saj evolucija pomeni postopni razvoj, spremembe organizmov pa so po veljavni teoriji prekinjenega ravnotežja skokovite.

Trémauxevo izhodišče je, da ne obstaja "problem vrst», temveč "vprašanje vrst«. Pri "vprašanju vrst" ne gre za definicije vrst, temveč za "izvor vrst», vprašanje, na katero se nanaša Darwinovo delo O izvoru vrst. Vrste različnih vej živalskega kraljestva, ki izhajajo iz istega izvora (prvobitna celica), so porazdeljene po obdobjih; v vsakem obdobju nekatere od teh vrst izumrejo, druge pa se še naprej razvijajo in delijo ter se po znakih vedno bolj razlikujejo.

Trémaux je po Morrissonu (2013) prispeval štiri filogenetične ugotovitve:

1. Prvi je narisal filogenetsko drevo po Darwinu. Drevo prikazuje nastanek in izumrtje vrst (speciacija) z notranjimi vejami kot predniki in listi kot ohranjenimi organizmi, povezuje

\footnotetext{
${ }^{3}$ O Trémauxevi knjigi je Marx leta 1866 pisal tudi svojemu prijatelju dr. Kugelmannu (1828-1902).
} 
pa vse zgodovinske veje nazaj do enega samega izvora, ki ga Darwinov diagram ne prikazuje. (slika 4)

2. Speciacija je skoncentrirana $v$ določenih obdobjih $v$ geološkem zapisu (meje med dobami). Z evolucijskim stanjem ravnotežja (angl. stasis) $v$ drugih obdobjih je predvidel teorijo prekinjenega ravnotežja Goulda in Eldredgea za več kot stoletje, čeprav ga ima Gould skorajda za diletanta. (slika 4)

3. Vrste nastajajo $v$ geografsko izoliranih populacijah. $S$ tem je prehitel idejo alopatrične speciacije Moritza Wagnerja (1813-1887) za tri leta, vendar Trémauxa Wagner sploh ne omenja, Darwin pa citira Wagnerja, in ne Trémauxa.

4. Trémaux je uporabil Darwinovo teorijo evolucije za razvoj homo sapiensa šest let, preden je to izrecno storil Darwin. Thomas Henry Huxley (1825-1895) je o tem pisal že leta 1863, vendar je njegova knjiga najbolj znana po razvpiti risbi, ki prikazuje transformacijski razvoj opic (Huxley, 1863) (slika 1).

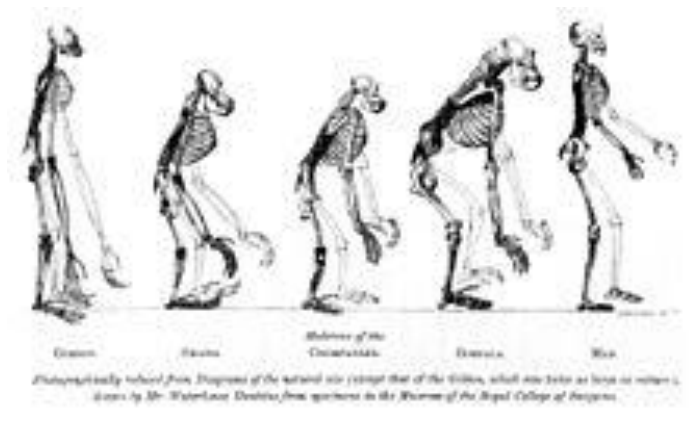

Slika 1: Risba za Huxleyjevo knjigo o človekovem mestu v naravi (1863), slika primerja skelete opic in človeka; gibon (levo) je dvojne velikosti

\subsection{Drevo}

Kar zadeva točko 1, je treba opozoriti, da Darwinov diagram drevesa ni povezan z njegovim opisom drevesa življenja. Diagram se uporablja za opis videnja razlike in potomca z modifikacijo; $v$ nobeni fazi se na ta diagram ni skliceval kot na drevo. Njegov opis diagrama in njegova pesniška evokacija svetopisemskega drevesa nimata nič skupnega. Da je Darwin narisal, kar danes imenujemo filogenetsko drevo, je le sodobna puhlica.

Leta 1865 je St. George Jackson Mivart (1827-1900) objavil prvo filogenetsko drevo z empiričnimi podatki. Od prve izdaje Darwinove knjige $O$ izvoru vrst leta 1859 je tako moralo miniti kar šest let, preden so biologi izdelali prvo empirično drevo. Darwin je, kot rečeno, objavil samo eno teoretično skico drevesa. Kasneje je Mivart postal eden najhujših Darwinovih kritikov (Morrison, 2012b). 
Slika 2: Mivartovo filogenetsko drevo, 1865 (cit. po Morrison, 2012b)

Darwinov diagram ni povezan z dnom, kot mora biti pri genealoškem drevesu. Darwinovi predhodniki so imeli pomisleke o vznožju drevesa, predvsem pri opisu diagramov fosilne zgodovine organizmov, in jih niso povezovali z enim samim izvorom. Trémaux ni imel takšnih dvomov in izrecno navaja en sam izvor, s katerim povezuje vse prednike.

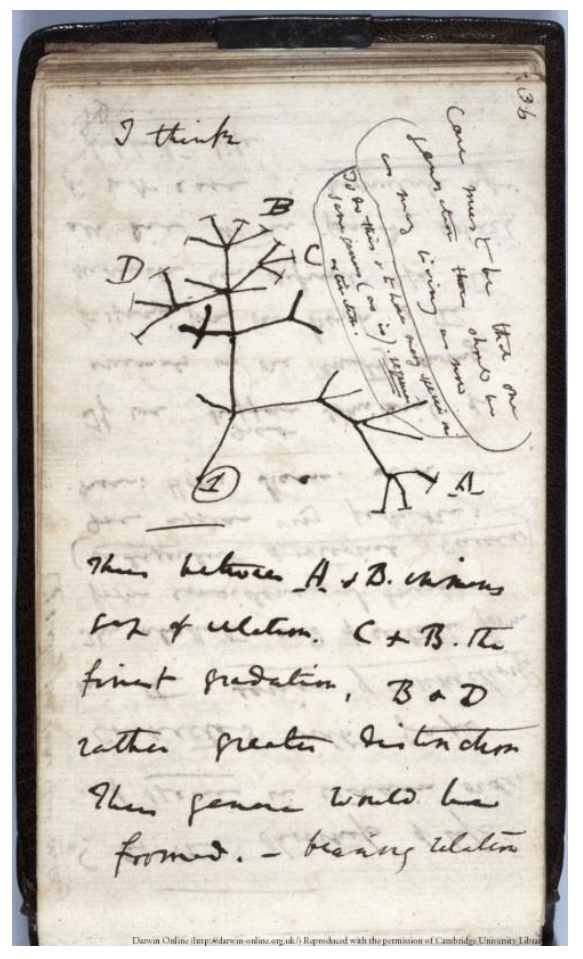

Slika 3: Slavna skica iz Darwinove beležnice B iz let 1837-38 (Notebook B, Darwin Online, 2016); prikazuje razvejen sistem prednikov z modifikacijo, ki jo je odkril; lahko pojasni odnos med različnimi vrstami $v$ isti družini (angl. family) 


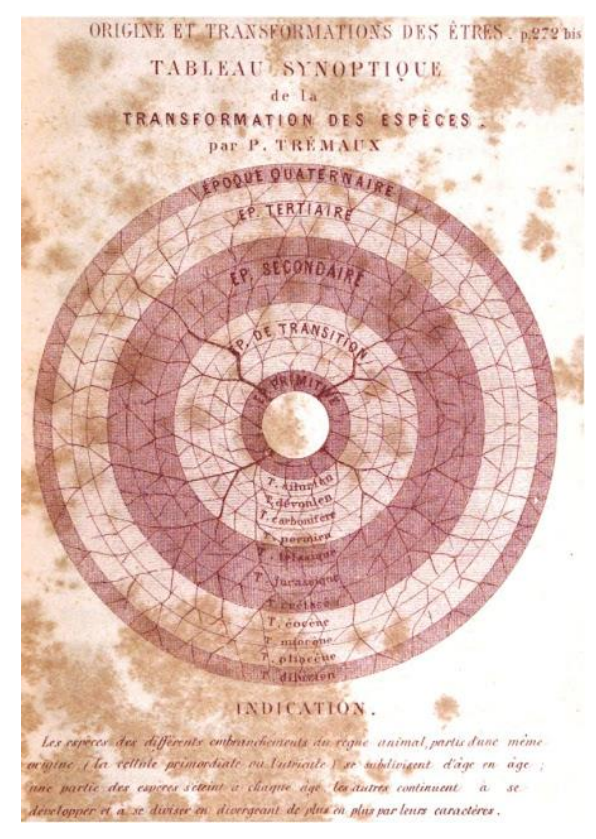

Slika 4: Trémauxevo filogenetsko drevo Izvor in transformacije bitij; sinoptična (pregledna) slika; transformacije (preoblikovanja) vrst po P. Trémauxu (Tremaux, 1865, vstavek med str. 272 in 273)

Zato je upravičeno trditi, da je Trémaux prvi objavil ponazoritev koncepcije filogenetskega drevesa $v$ obliki, $v$ kateri ga poznamo danes. Trémaux je izdelal (popolnoma neodvisno) tudi končno različico Darwinove skice iz zgodnjih petdesetih let 19. stoletja o odnosu med genealoškimi drevesi in geološko zgodovino (Morrison, 2012a). Zanimivo, da je imel Darwin v svoji knjižnici dva izvoda Trémauxeve knjige, vendar v njej očitno ni videl nič pomembnega in je ne citira (Wilkins in Nelson, 2008), čeprav vsebuje idejo, ki je bila enaka njegovi.

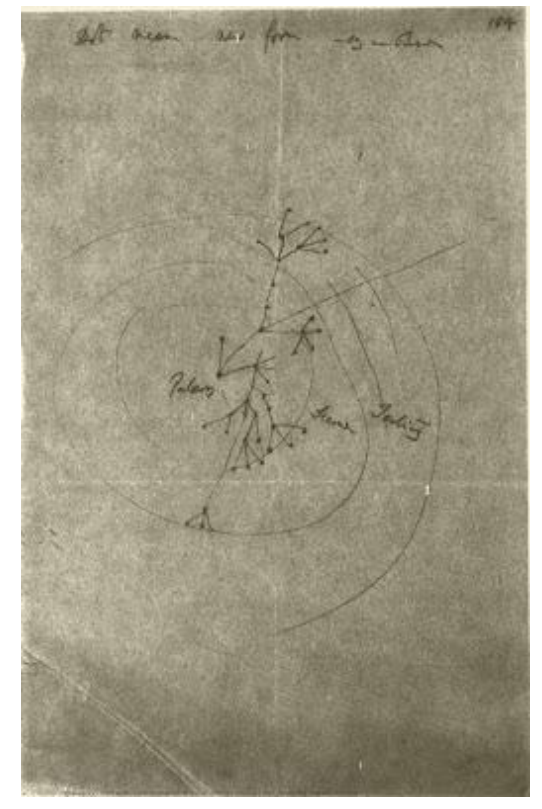

Slika 5: Darwinova skica iz zgodnjih petdesetih let 19. stoletja (Morrison, 2012a) 
Krožna drevesa so se ponovno pojavila šele v delu Englerja (1881), kjer koncentrični krogi predstavljajo različne morfološke značilnosti namesto geološkega časa, kar kaže na fenotipsko razliko v odnosu do skupnega prednika (skupaj z genealogijo, ki jo predstavlja drevo). Morrison (2014) je ugotovil, da so se v filogenetiki najprej uporabljale mreže kot metafore in modeli in šele 250 let kasneje, se pravi okrog polovice 19. stoletja, prispodobe drevesa kot modela za predstavitev odnosov med predniki in potomci v drevesu življenja (angl. Tree of Life, ToL).

Darwin je dajal prednost drevesu kot metafori pred mrežo, saj je bil osredotočen izključno na vertikalne genealoške odnose. Spoznal se je tudi na horizontalne dogodke v evoluciji, kot je hibridizacija, vendar jih ni integriral v svoje prispodobe $v$ obliki drevesa. Za mrežo v zvezi s pripadnostjo (angl. affinity) je uporabljal angleško besedo web, ne pa angleške besede network.

Vse metafore in modeli v znanosti kot sredstva za ponazoritev odnosov so aproksimativni, vendar so najbolj aproksimativne besede $v$ različnih jezikih, ki jih uporabljamo za komuniciranje spoznanj.

Po Platonu prilagajamo govor profilu komunikanta (Šercar, 1988). Tomaž Akvinski (ok. 12251274), ki je leta 1267 začel sestavljati in urejati Summa Thelologiae, se v različnih besedilih sklicuje na načelo in ga uporablja kot načelo razlage, ki se glasi »kar koli, kar je prejeto, je prejeto odvisno od tistega, ki prejema« (lat. quidquid recipitur ad modum recipientis recipitur) (St. Thomas Aquinas, 1267a). V Summa Theologiae (St. Thomas Aquinas, 1267b) najdemo še bolj specifično uporabo tega načela, in sicer, da »znana stvar obstaja v poznavalcu (učenjaku) $v$ skladu z načinom mišljenja le-tega« (lat. cogitum ... est in cognoscente secundum modum cognoscentis). $V$ moderni informacijski znanosti sta Wood in Saracevic (1981) razvila teorijo (ne da bi kot vir omenjala Platona), po kateri komunikator evalvira, strukturira, prepakira in konsolidira informacije $v$ sporočilu odvisno od komunikanta, ki mu je sporočilo namenjeno. Brez sklicevanja na vir je tudi načelo Tomaža Akvinskega, da so informacije konstrukt uporabnikov (Dervin, 1983), ki je uveljavljeno v sodobni informacijski znanosti.

Vrhunske biološke raziskave in obdelava ogromne količine podatkov, ki jih prinašajo poskusi na področju molekularne biologije, brez računalnikov in informacijske oziroma podatkovne znanosti preprosto niso več mogoče. Velikega dela rezultatov ni več mogoče opisati z uporabo naravnega jezika, za grafične prikaze in poglobljeno razumevanje pomena pridobljenih podatkov o kvantitativnem védenju bioloških sistemov, ki ga determinira genom, so nujno potrebni formalizmi iz računalništva (Brent in Bruck, 2006). 


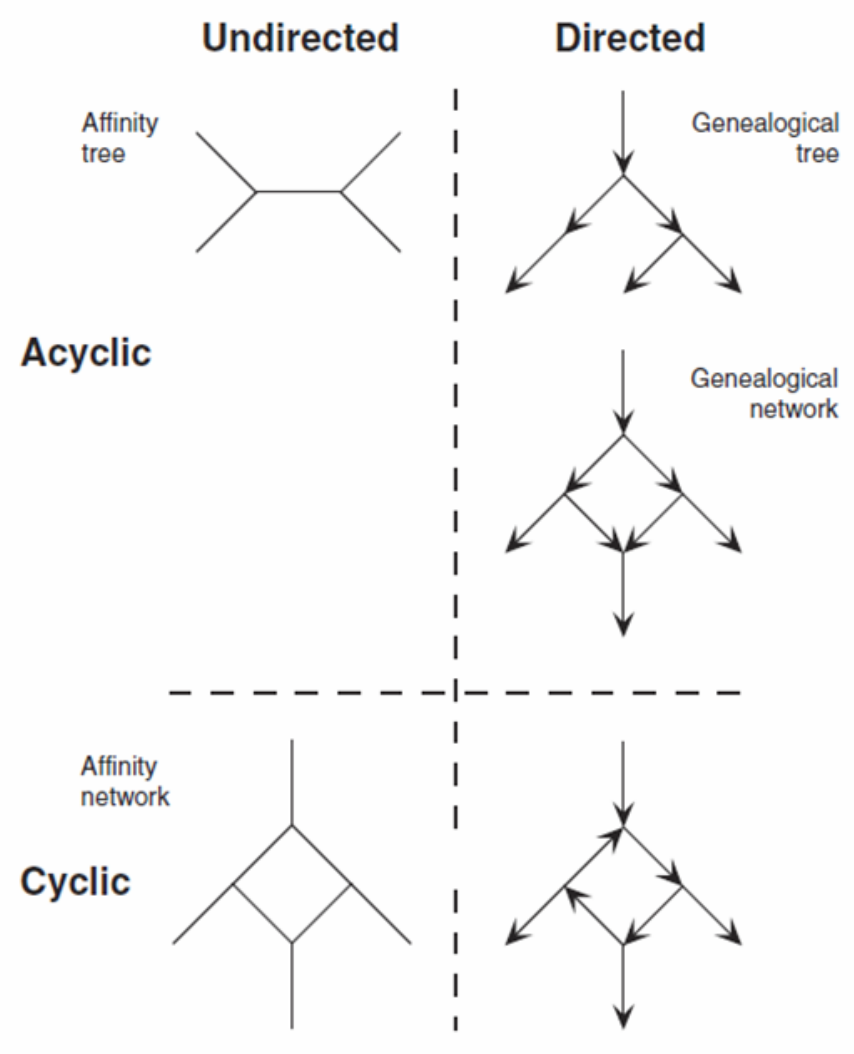

Slika 6: Razmerje med smermi in mrežami (Razmerje med smerjo in cikli v povezanem grafu. $V$ vseh grafih obstajajo štirje listi (brez oznak), čeprav je v usmerjenih grafih (desni stolpec) eden izmed njih skupni prednik. Število notranjih vozlišč in robov se razlikuje glede na to, ali obstajajo cikli (spodnja vrstica: 4 vozlišča, 4 robovi) ali ne (zgornja vrstica: 2 vozlišči, 1 rob; srednja vrstica: 4 vozlišča, 4 robovi) (Morrison, 2014, str. 631))

\subsection{Zemlja in habitat}

Wilkins in Nelson (2008) pokažeta, da sta veliko zmede povzročila tudi prevod in razumevanje francoske besede sol, ki je bila $v$ angleščino prevedena kot soil; tako se jo razume kot zemlja, in ne kot kot habitat (življenjski prostor). To je pripeljalo do sklepa, da Trémaux trdi, da je narava tal tisto, kar predvsem vpliva na evolucijo. Tako je zagotovo sklepal Stephen Jay Gould (1997, 1999a), ki je zapisal, da še nikoli ni prebral bolj absurdne in slabše dokumentirane teze.

Habitat je naravno okolje, v katerem živi rastlina ali žival, bivališče. S človekom je drugače. Človekovo bivališče, habitat, sestoji iz naravnega dela in kulture. Naravo je človek spremenil in večinoma uničil, kulturo pa je ustvaril sam. Nacija si lasti oboje kot osnovo za širjenje identitete, tako posameznika kot etničnega kolektiva. S stališča družbenega zemljepisa je habitat antropogeografija določenega področja, sestavljena iz naravnih in kulturnih elementov, ki so rezultat vpliva naravnih virov na dejavnosti narodnih in drugih številnih skupin ter delovanja slednjih na naravne in kulturne danosti s političnimi dejavniki vred (East, 1944). Pri zgodovinskem zemljepisu gre za zgodovinski pogled na pojave in procese fizične in družbene geografije, rezultat pa je nekaj tisoč let dela na področju, začenši z neposrednim 
opazovanjem, književnim opisovanjem ter spoznanji znanstvene arheologije in znanstvene zgodovine (Luthar et al., 2006) ${ }^{4},{ }^{5}, 6$.

Napredek in smiselnost sta vrednostni kategoriji, ki predpostavljata, da obstaja neko stanje kot cilj, proti kateremu je razvoj (človeštva) naravnan. Posameznik in družbene skupine lahko prispevajo $\mathrm{k}$ razvoju in s tem ta proces pospešijo, lahko ga tudi upočasnijo, vendar razvoja ne morejo preprečiti. Naša svoboda je odvisna od spoznanja resnice, tj. umnosti zgodovine. Po heglovskem panlogističnem versusu cancrinusu je umno obstoječe, obstoječe pa umno. Znanost tega ne potrjuje, saj so spremembe in transformacije $v$ naravi in družbi posledice naključja. Človek živi v svetu, ki ga je ustvaril sam, spremembe pa so odvisne od svobodne (prostovoljne) izbire namena in organiziranega delovanja posameznikov in skupin $v$ skladu $z$ načrtom ter od nešteto drugih naključnih dejavnikov $v$ naravi, družbi in kulturi, ki jih je nemogoče nadzorovati in upravljati. Brez človekove namenskosti je družbena zgodovina slepa, enako, kot je naravna zgodovina živih bitij naključje.

Najslabša in zgodovinsko najpogubnejša točka Marxove filozofije je ravno historični determinizem, na katerem je temeljilo njegovo preroštvo o zgodovinski nuji razvoja znanstvenega socializma. Nanj so se, kot vemo, sklicevali in se še sklicujejo boljševiki po vsem svetu. Predpostavka predvidevanja je determinizem. Predvidevanja so možna le pod pogojem, da pretekla socialna stanja determinirajo sedanja stanja, sedanja pa prihodnja stanja. Tega

\footnotetext{
${ }^{4}$ Naj navedem nekaj najpomembnejših antičnih avtorjev za področje zgodovinskega zemljepisa: Homer (9. st. p. n. št.; najstarejši grški pesnik; Iliada, Odiseja); Herodot iz Halikarnasa (5. st. p. n. št.; grški zgodovinar; Zgodovina, geografskoetnografsko gradivo); Tukidid (5./4. st. p. n. št.; poleg Herodota največji grški zgodovinar, utemeljitelj zgodovinske kritike, posebej vplival na Salustija in Tacita ter prek njiju na celotno kasnejšo historiografijo); Eratosten iz Kirene (3. st. p. n. št.; začetnik znanstvene geografije; Geografija, O meritvah zemlje); Polibij (2. st. p. n. št.; grški zgodovinar, Zgodovina); Posidonij iz Apameje (2./1. st. p. n. št.; polihistor, naravoslovni ogledi iz geografije, klimatologije in astronomije); Artemidor iz Efeza (2./1. st. p. n. št.; grški geograf; Geografski zapisi); Strabon (1. st. p. n. št.; grški geograf in zgodovinar; Geografija); Gaj Julij Cezar (100-44 p. n. št.; rimski državnik in vojskovodja; Commentarii de bello Gallico); Gaj Salustij Krips (86-35 p. n. št.; rimski politik in zgodovinar; Historiae); Plinij Starejši (23/24-79; rimski naravoslovec, zgodovinar; Naturalis historia, Bella Germaniae); Kornelij Tacit (1./2. st.; največji rimski zgodovinar; De origine, situ, moribus ac populis Germaniae); Zosim (5./6. st.; grški zgodovinar; Nova zgodovina - od prvih rimskih cesarjev do Alarihove zasedbe Rima leta 410 (Škiljan, 1996); Muhammad al-Idrisi (1100-1165; arabski geograf, kartograf, egiptolog, popotnik in botanik; zemljevid sveta iz leta 1154, izdelan za sicilskega kralja Rogerija II.; eden najboljših srednjeveških zemljevidov sveta).

${ }_{5}^{5}$ Rimsko cesarstvo, ustanovljeno leta 27 p. n. št. je do propada leta 476 predstavljalo edino organizirano državo v Evropi. Meje Rimskega cesarstva so bile hkrati tudi meje civiliziranega sveta. V naslednjem obdobju do oceanske faze, ki se je začela z odkritjem Amerike konec 15. stoletja, so Sveto rimsko cesarstvo nemške narodnosti, Bizantinsko cesarstvo in Arabski kalifat v Evropi obsegali ozemlja, kjer so prebivale številne skupine različnih narodnosti, jezikov in ver. Med vladavino Karla Velikega na prehodu iz 8. v 9. stoletje se je končala velika selitev narodov. Po propadu navedenih cesarstev so nastajale nove države približno po narodnem ključu, kot npr. Francosko kraljestvo in Nemško cesarstvo, kjer sta prevladovala en narod in en jezik. Od leta 1871 naprej so v Evropi nastale številne države, majhne po površini in številu prebivalcev, pred 2. svetovno vojno jih je bilo 28. Enako število držav v sedanji EU je zgolj naključje ... Te države lahko razdelimo na nekaj področij: manjšo atlantsko Evropo in večjo Evropo vzhodno od reke Visle, skandinavsko Evropo, Španijo in Balkanski polotok. Pasture je (2015) podal tisočletno zgodovino idej o evropski integraciji, ki je tesno povezana z implementacijo ideje o Evropi, izogibajoč se nevarnostim teleologije.

${ }^{6}$ East (1944) je prikazal vpliv političnih in kulturnih sprememb na zgodovinski zemljepis in antropogeografijo skozi več zgodovinskih obdobij različnih kolonizatorjev in zavojevalcev na primeru omejenega, a razmeroma velikega površja otoka Sicilija $\left(25.710 \mathrm{~km}^{2}\right)$, ki ima osrednji položaj v Sredozemlju. Sicilija je bila obljudena že v paleolitiku. Domnevni prebivalci so bili Ausoni, Sikani, Sikuli, Feničani, Grki, Rimljani, Arabci, Judi, Normani ..., kolonizatorji pa Feničani, Grki, Rimljani, Bizantinci, Arabci iz Tunisa in Normani (v 12. in 13. stoletju). Med oblastjo slednjih je bila Kraljevina Sicilija, Apulija in Kalabrija najnaprednejša in najbolj civilizirana država v Evropi. Ocenjujejo, da je imela 2 milijona prebivalcev (danes 5 milijonov), Anglija npr. je imela v istem času 1,5 milijona prebivalcev. Dohodek samo Palerma je bil večji od dohodka angleškega kralja v njegovi kraljevini. V posebnih četrtih Palerma so prebivali tudi Arabci, Grki, Latini, Judi in Normani, govorili pa so feničanski, grški, latinski, arabski in italijanski jezik.
} 
determinizma v družbenem življenju ni. Potemtakem so lahko predvidevanja le napačna ali pa predstavljajo srečno naključje (Šercar, 2007).

Devetnajsto stoletje je bilo obdobje nekaj pomembnih obratov in sprememb paradigem $v$ filozofiji in znanosti. Immanuel Kant (1724-1804), oče kritične filozofije nemškega klasičnega idealizma, je v Prolegomeni za vsako prihodnjo metafiziko (1783) napisal, da sta ga skepticizem in kritična filozofija Davida Huma (1711-1776) zbudila iz »dogmatičnega dremeža» in svojo Kritiko čistega uma opisuje kot rešitev Humovega problema v najobširnejši možni razsežnosti. Darwin je dejal, da je na njegovo teorijo evolucije vplivala predvsem kritična filozofska misel Davida Huma. Charles Darwin je postavil znanstveno teorijo o nastanku in evoluciji, ki se je kot nova paradigma uprla dotedanji prevladi teološkega kreacionizma in Lamarckovega idealizma.

Kreacionizem kot doktrino o nespremenljivosti vrst je v tridesetih letih 18. stoletja Carl Linné (1707-1778) formuliral takole: Tot numeramus species, quot ab initio sunt creatae. (Vrst je toliko, kolikor jih je od začetka ustvarjeno.) Species tot sunt diversae quot diversas formas ab initio creavit infinitum Ens. (Obstaja toliko vrst v različnih oblikah, kot jih je na začetku ustvarilo neskončno bitje.) Po teoriji transformizma oziroma evolucije se vrste spreminjajo in iz ene vrste lahko nastanejo tudi druge vrste.

Stephen Jay Gould in Niles Eldredge $(1972,1977)$ sta postavila model prekinjenega ravnotežja (angl. punctuated equilibrium), po katerem se evolucijske spremembe dogajajo naglo po dolgem obdobju stagnacije, za razliko od gradualizma, po katerem se evolucijski proces odvija postopno skozi daljše časovno obdobje. Wilkins in Nelson (2008) sta pokazala, da punktualizem, ki se pripisuje Eldredgeu in Gouldu, sploh ni nova ideja, saj jo najprej srečamo pri Trémauxu, Darwin pa jo je vključil v poglavje o geologiji v 4. izdaji knjige $O$ izvoru vrst iz leta 1866. Po Gouldu (2002) je na Darwina vplival Hugh Falconer (1808-1865), s katerim se je Darwin dopisoval, ne pa knjiga Pierrea Trémauxa, ki jo je imel v svoji knjižnici.

Vsaka vrsta mora iti skozi številne prehodne faze, obdobja, ko doživi spremembo, pa so zelo kratka v primerjavi z obdobji, ko vrsta ostaja nespremenjena. Zaradi tega dejstva ne najdemo neskončno varietet, ki bi povezovale izumrle in obstoječe oblike po najbolj postopnih korakih (Darwin, 1866).

Resnici na ljubo je Gould poleg Marxa in Engelsa ter Diane Paul edini pomembni znanstvenik, ki je zagotovo bral in komentiral Trémauxevo knjigo, žal, brez razumevanja, podobno kot Marx in Engels, ki s svojim dopisovanjem nista ravno prispevala $\mathrm{k}$ Trémauxevemu ugledu. Po drugi strani pa Trémauxeva antropološka in biološka dela ne bi doživela večje pozornosti, če jih Marx ne bi poveličeval.

Gould ni hotel priznati, da je bilo Trémauxevo stališče o evoluciji zelo blizu pogledu modela prekinjenega ravnotežja, saj bi tako zmanjšal izvirnost njune teorije. Gould (1999a) piše, da nikoli ni prebral slabše dokumentiranega dela. Trémaux v bistvu trdi, da narava tal (angl. soil) določa nacionalne značilnosti in da se višje civilizacije po navadi pojavijo na kompleksnejših zemljiščih in oblikujejo v poznejših geoloških obdobjih. Če je Marx res verjel, da takšen nedokazan nesmisel lahko presega pomembnost dela $O$ izvoru vrst, potem ni mogel pravilno razumeti in oceniti pomena Darwinovih spoznanj in idej. 


\section{Teorije nacionalnosti in ras}

Sodobna znanstvena teorija evolucije poleg naravne selekcije med naravne sile evolucije vključuje še mutacijo in genetski premik. Razen osnovnih sil v speciaciji (nastanek novih vrst) delujejo še dodatne sile. Glavni dejavnik je izolacija, ki je lahko geografska, ekološka, reproduktivna ali genetska. Spoznanje geografske izolacije, ki se danes imenuje alopatrična teorija o nastanku vrst, se pripisuje Moritzu Wagnerju (1873), ne pa Trémauxu, ki je o tem pisal tri leta prej (1868).

Nastanek in spremembe nacionalnosti in ras pojasnjujemo s štirimi teorijami: biološko, geološko, kulturno in socialno.

\subsection{Biološka razlaga}

Podobno usodo kot delo Pierra Trémauxa v razvoju geološke teorije je imelo epohalno delo Gregorja Johanna Mendla (1822-1884) v znanstveni genetiki. Svojo teorijo je Mendel predstavil v predavanjih članom naravoslovnega društva v Brnu leta 1865, leta 1866 pa objavil v Poročilih društva (torej istega leta, ko je Darwin objavil slavno 4. izdajo knjige $O$ izvoru vrst), vendar v Angliji in Franciji tega niso izvedeli.

Po Mendlovi teoriji dedovanja način prenosa lastnosti med živimi bitji skozi generacije določajo zakoni dednosti. Živo bitje prenese lastnosti na naslednjo generacijo z nečim, kar ostane nespremenjeno $v$ zaporednih generacijah organizma - danes vemo, da so to geni. $\mathrm{Na}$ videz izgubljene lastnosti, ki jih neka generacija izpusti, se lahko ponovno pojavijo $v$ drugi generaciji - gre za recesivne, prikrite, nevidne dedne lastnosti, ki jih prevladujoče, dominantne lastnosti potisnejo $v$ ozadje. Lastnosti, tako recesivne kot dominantne, se prenašajo matematično predvidljivo.

Mendlovo delo je začelo vplivati na razvoj znanstvene genetike šele leta 1900, 16 let po njegovi smrti in 34 let po prvi objavi, potem ko so ga pri pregledovanju literature (dobesedno) ponovno odkrili botaniki Hugo de Vries (1848-1932), Carl Correns (1864-1933) in Erich von Tschermak (1871-1962) v svojih raziskavah zakonitosti dedovanja, in to neodvisno drug od drugega. $^{7}$

\subsection{Geološka razlaga}

Avtor geološke teorije je Pierre Trémaux. Ista narava, iste sposobnosti oživijo na istem zemljišču (angl. soil). Zgodovinske in politične posledice Trémauxeve geološke teorije so po Marxu bolj pomembne in plodovite kakor Darwinova biološka teorija evolucije. Marx je $v$ omenjenem pismu Engelsu in Kugelmannu z odobravanjem komentiral trditev Trémauxa, da so črnci degenerirani belci, slednji pa naj bi bili višja rasa. Stališča Trémauxa o rasah so vplivala tudi na Marxove poglede na Slovane.

\footnotetext{
$7 \mathrm{Ni}$ verjetno, da je bila Mendlova "genska« teorija dedovanja spregledana prek 30 let zaradi morebitnih slabih komunikacijskih kanalov med Anglijo ter Češko in Moravsko, saj je začetek zadnje tretjine 19. stoletja doba prve industrijske revolucije $z$ uporabo parnega stroja in mehanizacije $v$ vsakdanjem življenju, železniški promet je že razvit, 19. stoletje je stoletje železnic, razdalje niso več predstavljale take težave kot prej, obstajali so telegrafija, poštni promet, množično komuniciranje, novinarstvo, časniki, znanstvene revije in druge oblike komuniciranja in informiranja $v$ znanosti $v$ Angliji, Franciji, Nemčiji, Avstriji ter na Češkem in Moravskem. Celo 500 let prej ni bilo ovir za hiter prenos idej Johna Wicliffa (13201384), ki je bil »jutranja zarja reformacije« v 14. stoletju v Angliji, v obliki spisov na Češko, kjer so vplivale na pojav »reformatorja pred reformacijo « Jana Husa (1369-1415). Mendlova teorija je predstavljala preobrat znanstvene paradigme na področju genetike in je bila preprosto pred svojim časom ravno za dobrih 30 let.
} 
Trémaux je bil pod vplivom dela Johanna Blumenbacha De generis humani varietate natura (O naravni raznovrstnosti človeštva, 1795), podobno tudi drugi predstavniki tedanje antropologije, sociologije, ekologije populacij in genetike. Podobno taksonomijo biološkega sveta je naredil Carl Linné in s tem prispeval k oblikovanju epistemološkega polja za razprave o metodah klasifikacije in hierarhije živih bitij. Namen Blumenbachove hierarhične taksonomije in klasifikacije je bil razvoj populacijske taksonomije, ki ima $v$ svojih predpostavkah teorijo čistega rasnega tipa oz. čiste rase. Neizogibna posledica takšnega pristopa je rasizem. Človeška vrsta ima pet variacij: kavkaško, mongolidno, etiopsko, ameriško in malajsko. Kavkaško rasno variacijo je Blumenbach poimenoval po pogorju Kavkaz. Gruzijci naj bi bili najlepša rasna variacija človeške vrste, kri Gruzijcev pa najboljša na svetu. Po E. A. Hootonu (1955), ki upošteva isto hierarhično-taksonomsko logiko, evropska populacija sestoji iz čistih Nordijcev, nordijskih Mediterancev, estonsko-baltske skupine itd. Ob upoštevanju te logike so bile variacije opredeljene na osnovi tipa las, barve kože, barve oči, obsega in oblike glave (frenologija).

Po Trémauxu se narava zemljišča (soil, habitat) sčasoma spreminja. Starejše plasti so manj popolne od plasti iz novejših obdobij. Obstaja vzporednica med dovršenostjo človeka in zemljišča. Zemljišče določa nacionalne karakteristike. Za razlike med rasami ni bistvena barva kože, ampak oblike. Ljudje s podobnimi karakteristikami stremijo živeti na isti vrsti zemljišča. Prebivalci Nove Fundlandije, ki živijo na starih plasteh, so vrsta črncev. Ameriški črnci so bližje ameriškim belcem kot avstralski aborigini. Obstaja toliko ras, kolikor je zemljišč različne vrste. Zemljišče diverzificira, oploditev (fekundacija) združuje. Prehrana lahko zmanjša vpliv zemljišča. Suženjstvo kot degenerativna sila lahko deluje $v$ nasprotju z vplivom zemljišča. Zaradi višje kvalitete zemljišča bo imel ameriški konfederalni, industrijski slabo razvit Jug tudi $v$ primeru zmage Severa vlogo upravljanja v Ameriki. Degenerirane rase so emigrirale na geološko slabša območja, Egipčani so se preselili na jug, v Sudan, degeneracija Majev je posledica migracije na zemljišče, ki je bilo manj popolno od ljudi.

Višje civilizacije nastajajo na boljših tleh, ki so nastala v kasnejših geoloških obdobjih. Rase nimajo več virov, ampak so posledica degeneracije skupnega prednika (monogeneza). Poleg selitve imajo ljudje tudi možnost izboljšati zemljišče (melioracija, izboljševanje zemlje z osuševanjem ali namakanjem, pogozditev, uporaba gnojila ...).

Medtem ko je napredek pri Darwinu čisto naključje, je pri Trémauxu nuja, ki jo določa geološki razvoj Zemlje. Marx je bil navdušen nad Trémauxevo teorijo bodisi zaradi stališča do napredka bodisi zaradi potrebe po iznajdbi znanstvene osnove za svoje rasne predsodke $v$ naravoslovju.

Engels je odgovoril Marxu, da je Trémauxeva geološka teorija neumnost, ker se Trémaux ne spozna na geologijo, prav tako tudi ni sposoben za kritično zgodovinsko mišljenje. Za razlike med Baski, Francozi, Bretonci in Alzačani je po njegovem krivo zemljišče, ne vidi pa, da ti ljudje govorijo štiri različne jezike. Prebivalci Porenja, ki živijo na plasteh iz devona, starih 500 milijonov let, bi se morali spremeniti v idiote in »nigre«! (Pozor: Beseda »niger « tedaj ni imela pejorativnega pomena, kot ga ima danes.) $\mathrm{V}$ naslednjem pismu je Engels omilil mnenje o Trémauxu, navkljub temu pa je bil prepričan, da se degeneracija ne more pojasniti na osnovi geologije. Človek je tisto, kar jé (Der Mensch ist, was er isst; Feuerbach). Arijske in semitske rase so bolj razvite zaradi koristnih učinkov obilice mleka in mesa, ki ga jedo. Indijanci v Mehiki, ki uživajo vegetarijansko hrano, imajo manjše možgane kot Indijanci na nižji stopnji barbarstva, ki jedo več mesa in rib. Engels je tako pod vplivom teorije Lewisa Henryja Morgana (1818- 
1881) razmišljal o povezanosti živalskih beljakovin in velikosti možganov (Morgan, 1877). Čeprav je bil abolicionist in za odpravo suženjstva, je bil Morgan prepričan, da je črna rasa zaostala in da bo izumrla, če se osvobodi neenakopravnosti. Zavračal je stališče, da imajo vse rase skupno poreklo. Mimogrede: $\mathrm{V}$ besedilih za javnost sta bila Marx in Engels $v$ ameriški državljanski vojni na strani črncev.

Po Johannu Gottfriedu Herderju (1744-1803), nemškemu pesniku, prevajalcu, teologu in filozofu, imajo narodi prirojene lastnosti, podobno kot osebe. Zgodovina je umna. Vsak narod ima duha in poslanstvo ter pravico do obstoja in nacionalnega gibanja. Vse to je dano narodu (od Boga) enkrat in za vselej. $S$ to teorijo je Herder sprožil razvoj modernih nacionalizmov ${ }^{8}$.

\subsection{Socialna razlaga}

Družbeno teorijo je Marx predstavil v Kapitalu (Vol. III, del VI, pogI. XLVII, II, 1999), na rasne razlike vpliva družbenozgodovinski razvoj:

"Specifična gospodarska oblika, $v$ kateri se neplačano presežno delo izžema iz neposrednih producentov, določa odnos gospodovanja in hlapčevanja, kot raste neposredno iz produkcije same in sam spet odločujoče vzvratno vpliva nanjo. Na tem pa temelji celotna zgradba ekonomske, iz produkcijskih odnosov samih rastoče skupnosti in s tem obenem njena specifična politična podoba. $V$ neposrednem odnosu lastnikov produkcijskih pogojev do neposrednih producentov - v odnosu, katerega vsakokratna oblika vselej naravno ustreza določeni razvojni stopnji načina dela in zato njegove družbene produktivne sile - najdemo vsakokrat najglobljo skrivnost, skriti temelj celotne družbene zgradbe in zato tudi politične oblike odnosa suverenosti in odvisnosti, skratka, vsakokrat specifične državne oblike. To ni ovira, da ne bi mogel isti ekonomski temelj - isti po glavnih pogojih - zaradi neštetih različnih empiričnih okoliščin, naravnih pogojev, rasnih odnosov, od zunaj delujočih zgodovinskih vplivov itd. kazati

\footnotetext{
8 V članku Serbische Lieder piše Goethe (1823) o Srbih kot o eni od tistih v splošnem nesrečnih polnacij (nem. unglückliche Mittelnationen), ki se ne znajo same vzpostaviti in ustvariti ravnovesja s sosednjimi silami. Z nemško-srbskim zbliževanjem se je celo življenje ukvarjal Jernej Kopitar (1780-1844; slavist, filolog, publicist in slovenski preroditelj). Leta 1823 je organiziral obisk Vuka Stefanovića Karadžića (1787-1864) pri Goetheju v Weimarju (Bašić, 1991). Tudi po Isaacsovi teoriji (1957) so nacije vedno obstajale in jih je treba samo odkriti. Glede na nasprotni pogled nacija ni statična družbena entiteta in nastanek nacije ne temelji na prvotnih značilnostih, pač pa gre za zgodovinske tvorbe, na nastanek katerih močno vplivajo tudi zgodovinske osebnosti na različnih ravneh. Nacije so novejše tvorbe, ki so nastale iz izbranega nabora potencialnih značilnosti in predstavljajo »domnevno skupnost « (Hobsbawm, 1990; Anderson, 1991). Nacije so nastale iz etnij (Smith, 1991). Definicija etnije vključuje več atributov: kolektivno ime, mit o skupnih prednikih, enega ali več razlikovalnih elementov skupne kulture, povezanost z domovino kot ozemljem, občutek solidarnosti za dele prebivalstva glede na rojstni kraj. Ko te atribute združijo tri revolucije (politična, gospodarska in kulturna), nastane nacija. Nacionalizem kot izključnost pa ni prebujena nacionalna samozavest, kot menijo nacionalisti. $V$ resnici si nacionalizem izmišlja nacijo tam, kjer je ni. Konkretne vsebine besede nacionalizem se razlikujejo v svoji singularnosti. Nacionalizmi se med seboj pogojujejo tako, da je vzrok enega nacionalizma $v$ drugem nacionalizmu, s katerim je v spopadu glede na nasprotne si cilje, in tak "vzorec prepoznavanja « kot skupek »nacionalnih sporočil« ima prednostno mesto v družbeni komunikaciji in pomen v procesu odločanja. Na vprašanje o motivih opredeljevanja za nacionalizme naj bi dale odgovor empirične socialno-psihološke raziskave o vlogi nacionalizmov $v$ individualnem in socialnem življenju. Možna je le tipologija nacionalizmov kot sredstvo hevrističnega opisa konkretnega nacionalizma (Behschnitt, 1992). Nacionalizem je zadnji stadij komunizma, pri katerem je razredni kolektivizem zamenjan z nacionalnim kolektivizmom. Ključni korak v oblikovanju nacionalne identitete je bil tiskarski stroj, saj je tisk dejavnik homogenizacije pri razvoju nacionalnega jezika. Pri oblikovanju nacionalnih identitet je pomembna tudi industrializacija. Moderna industrijska država lahko deluje samo, če obstaja mobilno, pismeno in kulturno homogeno prebivalstvo, sposobno za izmenjavo (Gellner, 1983). Obstajajo pa značilnosti, ki težko izginejo pred oblikovanjem nacionalne identitete in niso enakomerno razporejene $v$ družbi. Jezik (do neke mere), rasa in religija so takšne entropijsko odporne značilnosti, ki lahko zavirajo oblikovanje nacionalnih entitet.
} 
$v$ svojem pojavu neskončnih variacij in stopenj, ki jih je mogoče razumeti samo, če analiziramo te empirično dane okoliščine. " (Marx, 1999, str. 6-7 od 21)..$^{9}$

Marx je z družbeno teorijo zavrnil biološke elemente. Poudarjal je pozitivno stran lamarkizma. Biološke degeneracije so reverzibilne. Degeneracija in rasne razlike so zgodovinska posledica in se na enak način na osnovi zgodovinskega napredka lahko tudi odpravijo.

Engels je bil mnenja, da imajo Bušmani in aborigini dedne težave pri obvladanju matematičnih aksiomov, samoumevnih za osem let starega otroka, ki pripada razviti rasi, pri kateri so pridobljene značilnosti postale že dedne.

Marx je delal taktične izjeme (tako kot tudi Engels) in odstopal od svoje glavne, družbene teorije $v$ smeri nacionalizma, kolonializma in rasizma, predsodki v zvezi z nacijami in rasami pa so politično nevarni in osebno žaljivi. Znani rek, da izjeme potrjujejo pravilo, je posledica slabega prevoda in se pravzaprav glasi, da vsaka izjema pravilo postavlja pod vprašaj! Odkritje črnega laboda po metodi falsifikacije poruši trditev, da so vsi labodi beli.

Po Paulovi (1981) je pomembno vprašanje, v kolikšni meri so na kategorije devetnajstega stoletja vplivali rasni predsodki Marxa in Engelsa, ki predvsem glede rasnega vprašanja in kolonializma nista bila ravno napredna. Njuni rasni predsodki se nanašajo na črnce, Mehičane, Irce in Slovane, predvsem na Južne Slovane, še natančneje, na Hrvate in Srbe. Vendar vse filozofije, vključno z marksizmom, kažejo nekatere predpostavke časa, v katerem so nastale (Lukacs, 1986).

"Znanstveni« socializem Karla Marxa ima isto, starozavezno paradigmo in je usmerjen na (Jude kot) nosilce kapitalizma. Kot negacija kapitalizma je hkrati tudi rešitev judovskega vprašanja v odprti družbi svobodnih posameznikov, v kateri se bosta izmenjavala ljubezen za ljubezen in zaupanje za zaupanje, ne pa denar za denar (Marx, 1844/1961).

Obrazec antisemitizma krščanskega apostola Pavla iz Tarza, ki se je iz najhujšega sovražnika kristjanov spreobrnil v kristjana in iz Savla prekrstil v Pavla, in sovraštva do dela lastnega naroda, ki je zavrnil krščanstvo Jezusa Kristusa, se ponovi pri Karlu Marxu, Ottu Weiningerju (1880-1903), Ludwigu Wittgensteinu (1889-1951) in Simone Weil (1909-1943). »Ubij Juda, zažgi mu kontoar in tvojih dolgov ne bo več. « (Steiner, 2011, p. 111) ${ }^{10}$.

\footnotetext{
${ }^{9}$ Vedno sem govoril, da bi Marx dobil Nobelovo nagrado, če bi ta obstajala v času njegovega življenja (Marx se je rodil 5. maja 1818, umrl pa leta 1883; Nobelova nagrada se redno podeljuje od leta 1901; nagrada za ekonomske vede je bila uvedena leta 1968). Marx je bil znanstvenik in mislec, ki so ga za preroka in odrešenika človeštva po obrazcu Stare zaveze razglasili kvazi komunistična gibanja in režimi.

10 O tem pričajo masaker v Poznanju med Prvo križarsko vojno (1095-1099), inkvizicija, pregoni Judov iz Svetega nemškega cesarstva pod obtožbo, da so krivi za »črno smrt« (14. stoletje), nato naselitev mnogih Judov v Avstriji, na Češkem in Poljskem, potem pa pregoni iz Avstrije vključno s Slovenijo, Pirenejskega in Apeninskega polotoka (konec 15. stoletja) in plinske peči holokavsta med 2. svetovno vojno kot uresničitev nacistične ideologije dokončne rešitve judovstva. Frančiškan Sv. Janez Kapistran, reformator in pridigar iz 15. stoletja, ki je živel in deloval tudi v lloku na Hrvaškem, je kot možno rešitev predlagal, da bi »sovražnike vere« vkrcali na ladje in jih poslali na ocean. Glavni neodpustljiv greh Judov je, da so. Slepilo bo padlo na Izrael zaradi zavračanja križanega Kristusa. „Če pa je naš evangelij kljub temu zakrit, je zakrit za tiste, ki so na poti pogubljenja, za nevernike, ki jim je bog tega sveta (tj. hudič, op. avt.) zaslepil misli, tako da jim ne zasveti razsvetljenje evangelija o veličastvu Kristusa, ki je podoba Boga." (2 Kor 4, 3-4). Judje, ki so izumili in ustvarili Boga, so Boga v osebi Jezusa Kristusa tudi "ubili«. V govoru na Sveti Gori Jezus Kristus ponavlja sestavine učenja preroka Izaije in Jeremije: Ne skrbite za jutri, ljubite sovražnike, ne sodite, da ne boste sojeni, ljubite svojega bližnjega kot samega sebe! Bodite popolni, kot je popoln Oče vaš nebeški! Naj citiram evangelista Luka (6. 27-42): „Vam pa, ki poslušate, pravim: Ljubíte svoje sovražnike, delajte dobro tistim, ki vas sovražijo. Blagoslavljajte tiste, ki vas preklinjajo, in molíte za tiste, ki grdo ravnajo z vami. Tistemu, ki te udari po enem
} 
Marxov spis o judovskem vprašanju (Zur Judenfrage) je njegova recenzija del Bruna Bauerja (1809-1882) na to temo iz leta 1843 (objavljena leta 1844) in ni antisemitski iz dveh razlogov. Marxov stereotip ekonomskega Juda vsebuje veliko elementov resnice. Judi so po izključitvi iz sistema srednjeveških stanovskih združenj trgovcev in obrtnikov prevzeli osrednjo vlogo pri ustvarjanju denarja, ekonomiji kot znanosti o ustvarjanju denarja, kontroli mednarodnih financ, hrepenenju po dobičku in razvoju kapitalizma. Politična emancipacija Judov in pridobivanje politične enakosti hic et nunc, tukaj in zdaj, ki je bistvo moderne sekularne države, osvobojene odvisnosti od religij, ne more čakati na uresničitev splošne družbene emancipacije, ki se bo zgodila nekoč $v$ prihodnje. Družbena emancipacija Judov je emancipacija družbe od judovstva.

Med utemeljitelji modernizma (Darwin, Marx, Freud, Einstein ...), ki so, kot pravi Steiner (2011), klima zahodne zavesti, samo Darwin ni Jud. Steiner meri na pesem In Memory of Sigmund Freud (verz iz pesmi: "an important Jew who died in exile") iz zbirke Another Time W. H. Audna iz leta 1940, v kateri med drugim piše: " for one who'd lived among enemies so long: / if often he was wrong and, at times, absurd, / to us he is no more a person / now but a whole climate of opinion«.

V vlogi nosilcev kapitalistične gospodarske rasti in ekonomske uspešnosti vidi Max Weber (1864-1920) (2001) severne evropske protestante in njihovo etiko, spregleda pa druge religije in etnične skupine, predvsem Jude in Kitajce. Obstaja povezanost med religijo in gospodarskim razvojem. Razen etičnih norm obstajajo tudi drugi dejavniki, ki vplivajo na gospodarsko rast, vendar so določene osebnostne značilnosti najpomembnejše. Kadar te značilnosti pridobijo status veljavne morale, spodbujajo ljudi, da ravnajo skladno s to etiko tudi v podjetništvu in pri delu.

\subsection{Kulturna razlaga}

Da so se že v starem veku spoznali na moč kulture, priča Horacijevo priznanje: „Graecia capta ferum victorem cepit et artes intulit agresti Latio « (Zasedena Grčija je premagala divjega zavojevalca in kmetavzarski Laciji prinesla kulturo) (Quintus Horatius Flaccus, Epistvlarvm, ok. 20-13 pr. n. št.). Rimljani so osvojili Grčijo vojaško in politično. Toda premagana Grčija je kulturno zmagala. Rimljani so se »pogrčili« in postali nosilci grške kulture.

Po Marxu je kultura kot del družbene nadstavbe odraz ekonomije. Marxov prispevek je bil predvsem $v$ tem, da je odkril povezanost med tema spremenljivkama. Max Weber (18641920) je obrnil to tezo tako, da se glasi: družbena nadstavba vpliva na ekonomsko bazo. $V$ obeh primerih gre za poenostavljanje z uporabo razmeroma enostavnega modela z dvema spremenljivkama. Latourova teorija akter-omrežje (angl. actor-network theory, ATN) pa pokaže, da je teh dejavnikov ogromno, povezave s povratnimi zankami med njimi pa so tako zapletene, da jih je praktično nemogoče obvladati (Latour, 1998). Pravzaprav gre za

\footnotetext{
licu, nastavi še drugo, in kdor ti hoče vzeti plašč, mu tudi obleke ne brani. Vsakemu, ki te prosi, dajaj, in če kdo vzame, kar je tvoje, ne zahtevaj nazaj. In kakor hočete, da bi ljudje storili vam, storite vi njim. Če ljubite tiste, ki ljubijo vas, kakšno priznanje vam gre? Saj tudi grešniki ljubijo tiste, ki njih ljubijo. Če namreč delate dobro tistim, ki delajo dobro vam, kakšno priznanje vam gre? Tudi grešniki delajo isto. In če posojate tistim, od katerih upate dobiti nazaj, kakšno priznanje vam gre? Tudi grešniki posojajo grešnikom, da prejmejo enako. Vi pa ljubíte svoje sovražnike. Delajte dobro in posojajte, ne da bi za to kaj pričakovali. In vaše plačilo bo veliko in boste sinovi Najvišjega, kajti on je dober tudi do nehvaležnih in hudobnih. Bodite usmiljeni, kakor je usmiljen tudi vaš Oče! Ne sodite in ne boste sojeni. Ne obsojajte in ne boste obsojeni. Odpuščajte in vam bo odpuččeno. Dajajte in se vam bo dalo; dobro, potlačeno, potreseno in zvrhano mero vam bodo nasuli v naročje. S kakršno mero namreč merite, s takšno se vam bo odmerilo."
} 
metodološko vprašanje o tem, katere dejavnike (enega ali več) bomo opredelili kot neodvisne spremenljivke, in sicer pod pogojem, da jih je sploh mogoče določiti in uspešno uporabiti za namene teoretičnega premišljevanja in znanstvenega raziskovanja. Primat katere koli sfere je predpostavka. Avtoritarne etatizme legitimira npr. prevlada političnih prerogativov države nad družbo, četudi politični in upravni sistem ne sodeluje v gospodarskem življenju; to velja tako za avtoritarni državni socializem kot za vojaške diktature.

Daniel Bell (1972) je podal razvoj kulturnih protislovij kapitalizma. Gospodarska rast je sekularna religija razvitih industrijskih družb in raison d'etre kapitalizma. ${ }^{11}$ Ameriški klasični kapitalizem je temeljil na moralnem sistemu nagrad in plačil. Ta sistem je imel korenine $v$ protestantski posvetitvi dela, ki naj bi zamenjalo hedonistične obljube materialnega ugodja, pohote in razkošja.

Moderna umetnost oziroma kultura od 19. stoletja naprej ni več odraz osnovne družbene strukture. Kult umetnosti je nadomestil že izčrpani kult krščanstva in postal novi kult - primat in neodvisnost kulture pri ustvarjanju socialnih sprememb sta bila dokončno priznana. To dejstvo je prvi razkril francoski tehnokrat in socialist grof Henri de Saint-Simon (1760-1825). Z družbeno strukturo vlada gospodarsko načelo racionalnosti, $v$ kulturi pa prevladuje antiracionalni značaj. Družbena struktura v devetnajstem stoletju, ki sloni na samodisciplini, zapoznelem zadovoljstvu in zadržanosti, je v ostrem spopadu s kulturo, ki zavrača meščanske vrednote, delno tudi zaradi učinkov kapitalističnega gospodarskega sistema, predvsem pa zaradi prostega trga.

Po teoriji Maxa Webra se je v vseh umetnostih pojavilo razbitje racionalne "kozmologije«. V nasprotju tudi z Marxovo teorijo o kulturi kot odrazu gospodarstva je umetnost postala avtonomna, umetniki ustvarjalci okusa. Družbeni razred ali drug položaj umetnika ne določa več njegovega življenjskega sloga in sistema vrednot. Umetniki oblikujejo javni okus, buržujski razred in kupci umetnin ne kontrolirajo več umetnosti. Buržujske vrednosti so odvržene. Buržoazija obravnava kulturo kot blago in pri izmenjavi uporablja snobovske vrednote, kar povzroča napetost med kulturo (tj. umetniki) in delom družbe, ki umetnost konzumira in kupuje. S pojavom modernizma $v$ devetnajstem stoletju se je začel spopad med kulturo in socialno strukturo, ki traja še dandanes.

Samozavest in neodvisnost umetnikov je prišla do polnega izraza npr. v nagovoru v slogu vede o govorjenju ameriške igralke Meryl Streep, nagrajenke za življenjsko delo, ob podelitvi zlatih

\footnotetext{
11 Po Davidu Ricardu (1772-1823) in Karlu Marxu imata lahko nepravična distribucija kapitala in razredna struktura družbe strahotne posledice. Največji delež bogastva, proizvodnje in dobička si lastijo zemljiški posestniki (Ricardo) oziroma industrijski kapitalisti (Marx). Socialno-ekonomski in politični ekvilibrij v kapitalizmu ni mogoč. Brezmejna akumulacija kapitala in koncentracija bogastva $v$ majhnem številu rok grozi z meddržavnimi vojnami in državljanskimi napetostmi, spopadi in revolucijami. Na začetku 20. stoletja je Rusija krenila po poti družbene revolucije, čeprav se je tam industrijska revolucija komaj začela, najrazvitejše države Evrope in Amerike pa po poti socialne demokracije. Benjamin M. Friedman (2006) pokaže, da ima gospodarska rast povratne pozitivne moralne posledice. Gospodarska rast vpliva na življenjski standard, ki naredi družbo bolj odprto, strpnejšo in bolj demokratično, teh kvalitet pa ne vrednotimo s tržnimi, ampak z moralnimi merili. Teorija Benjamina Friedmana temelji na kvantitativni gospodarski zgodovini Simona Kuznetsa (1901-1985), ameriškega ekonomista, statistika, demografa in ekonomskega zgodovinarja beloruskega rodu, Nobelovega nagrajenca za področje ekonomije za leto 1971, ki je verjel v možnost harmonizacije med družbenimi razredi. Ravnotežje sil rasti, konkurence in tehnološkega razvoja pelje k zmanjšanju neenakosti. Filozofijo Simona Kuznetsa v povzeti obliki predstavlja stavek: »Rast je naraščajoča plima, ki dviguje vse čolne!« (Kuznets, 1971). Glavna sila neenakomerne distribucije bogastva po Thomasu Pikettyju (2014) je, da je dobiček od kapitala večji od gospodarske rasti (dobiček > rasti). Ta sila je močnejša od sil konvergence, kot so znanje in spretnosti, naložbe $v$ izobraževanje, ponudba in povpraševanje ter mobilnost kapitala in delovne sile, ki zmanjšujejo neenakost. Če upoštevamo vse skupaj, kapitalizem neizogibno pelje k rasti neenakosti.
} 
globusov 8. januarja 2017, na spopad pa kažejo živčni in žaljivi odzivi najvišjih predstavnikov nove strukture $v$ ZDA kot nadaljevanje napadov na umetnost, tujce in medije.

\subsection{Rasni predsodki - Slovani}

Marx in Engels sta dosledno podpirala borbo irskega naroda za neodvisnost, čeprav sta zelo izpostavljala njihove slabe lastnosti, nasprotne lastnostim, ki označujejo stereotip Juda. Problem Ircev ni rezultat njihove biološke narave, ampak zatiralskega in nasilnega tujega družbeno-političnega režima.

Marx in Engels sta bila kot Nemca vse življenje obremenjena s predsodki o Slovanih. Njuno mnenje o Slovanih je tako slabo, da predstavljajo njuni razmeroma realni potreti črncev, Judov in Ircev pravo laskanje (Paul, 1981). Rešitev za slovansko vprašanje po njunem mnenju ni v splošni družbeni emancipaciji, ampak $v$ eksterminaciji Slovanov kot naroda $॥ v$ interesu civilizacije«. Kot narodom »brez zgodovine«, ki ne spremljajo smeri zgodovinskega razvoja, ki pelje v kapitalizem, Engels (1849) Slovanom ni priznaval niti pravice do samoopredelitve in je branil nemško hegemonijo nad Slovani in ameriški ekspanzionizem proti mehiškemu narodu. Čehom in Južnim Slovanom, ki so podobni »lenim« Mehičanom, manjkajo zgodovinski predpogoji za neodvisnost, slovanski nacionalizem pa je nujno kontrarevolucionaren. Poljake in Ruse sta imela za izjeme. Rusi (Moskoviti) so tatarizirani in mongolizirani Slovani, ki se znatno razlikujejo od Zahodnih in Južnih Slovanov.

Marx in Engels (1853) sta o Južnih Slovanih pisala v člankih, objavljenih v New York Tribune, ki obravnavajo krimsko vojno (maj 1853-marec 1856) med Rusijo na eni strani ter Veliko Britanijo, Francijo, Kraljevino Sardinijo in Turčijo na drugi strani ter o ruskih grožnjah Evropi. V prvi polovici 19. stoletja so Rusi podvojili ozemlje svoje države, in to z lahkoto, zahvaljujoč pasivni geopolitiki zahodnoevropskih držav, in sicer predvsem do Turčije.

Pravita, da je treba ločiti Južne Slovane v habsburški monarhiji od Južnih Slovanov v Turčiji, čeprav govorijo isti jezik, in to glede na družbeno-ekonomski položaj. Slovani v habsburški monarhiji spadajo v najnižji družbeni sloj, medtem ko Slovani pod Turki opravljajo višje in zelo visoke poklicne dejavnosti $v$ državi. Slovanski narodi $v$ habsburški monarhiji nimajo prihodnosti, kajti manjkajo jim najelementarnejši zgodovinski, geografski, politični in industrijsko-kapitalistični predpogoji za samostojnost in zmožnost za življenje. To so narodi, ki so od prve stopnje civilizacije naprej pod tujo prevlado:

Zdaj pridemo do rase, ki tvori večino prebivalstva in katere kri je prevladujoča, kadar koli se rase mešajo. Dejansko lahko rečemo, da tvori glavni material za krščansko prebivalstvo od Mure do Donave in od Črnega morja do Arnavtskega gorovja. Ta rasa je slovanska rasa, še posebej tista njena veja, ki jo imenujejo ilirska in južnoslovanska (Yugoslavyanski). Poleg Zahodnih (Poljakov in Čehov) in Vzhodnih Slovanov (Rusov) predstavlja tretjo vejo te številne slovanske družine, ki je zadnjih dvanajst stoletij zasedala vzhodni del Evrope. Južni Slovani ne zasedajo le večjega dela Turčije, ampak tudi Dalmacijo, Hrvaško, Slavonijo in južni del Madžarske. Vsi govorijo isti jezik, ki je precej podoben ruskemu in za ušesa Zahodnjakov daleč najbolj muzikalen od vseh slovanskih jezikov. Hrvati in del Dalmatincev so rimokatoliki, vsi drugi pa pripadajo grški cerkvi. Rimokatoliki uporabljajo latinsko abecedo, privrženci grške cerkve pa pišejo svoj jezik s ciriličnimi črkami, ki se uporabljajo tudi $v$ ruskem ter staroslovanskem in cerkvenem jeziku. Ta okoliščina skupaj z razliko v veroizpovedi je ovirala nacionalni razvoj celotnega južnoslovanskega ozemlja. Beograjčan morda ne more brati 
knjige, natisnjene v njegovem jeziku v Zagrebu ali Pečuhu, lahko celo ugovarja temu, da bi jo sprejel, in to zaradi »heterodoksne" abecede in pravopisa, ki se uporabljata v njej; pri branju in razumevanju knjige, natisnjene v Moskvi v ruskem jeziku, pa bo imel le malo težav, ker sta ta dva jezika (ruski in srbski), še posebej v starem slovanskem etimološkem pravopisnem sistemu, zelo podobna in ker je knjiga natisnjena $v$ »ortodoksni« (pravoslavni) abecedi. Množica grških Slovanov sploh nima svoje Biblije, liturgij in molitvenih knjig, natisnjenih v svoji domovini, ker so prepričani, da obstajajo posebna pravilnost in ortodoksnost ter vonj svetosti $v$ vsem, kar je natisnjeno $v$ sveti Moskvi ali v cesarskih tiskarnah Sankt Peterburga. Kljub vsem panslavističnim prizadevanjem navdušencev $v$ Zagrebu in Pragi imajo srbska, bolgarska in bosanska raja (tur. rayah pomeni čreda, op. prev.) ter slovanski kmetje v Makedoniji in Trakiji več nacionalnega sočutja, več stičnih točk, več načinov intelektualne povezanosti z Rusi kot z rimskokatoliškimi Južnimi Slovani, ki govorijo isti jezik. Kar koli se zgodi, vsi se obračajo proti Sankt Peterburgu in pričakujejo prihod Maziljenca (Mesije), ki jih bo rešil hudega; in če imenujejo Konstantinopel naš Carigrad in Cesarsko mesto, je to bolj $v$ pričakovanju pravoslavnega carja, ki prihaja s severa in vstopa vanj, da obnovi pravo vero, kot pa v spominu na ortodoksnega carja, preden so Turki zasedli mesto. (Marx in Engels, 1853, I)

Od leta 1815 je obstajala Kneževina Srbija pod zaščito Rusije (od leta 1882 Kraljevina Srbija). Nova politična realnost je silila Srbijo, da okrepi odnose z Zahodno Evropo. Začela se je uveljavljati civilizacija (kapitalizem) ... (Marx in Engels, 1853).

Marx je bil ideolog napredka, ki vključuje kapitalizem kot neizogibno pripravljalno razvojno fazo za prehod $v$ humanejšo družbo, ki bo predstavljala konec zgodovine. Na kapitalizem se je spoznal in ga je goreče zagovarjal kot malokateri meščanski filozof, antropolog, sociolog, ekonomist in politični aktivist. Bil je teoretik, analitik in obenem tudi brezkompromisni kritik kapitalističnih družbenih odnosov. Kot radikalni demokrat je nasprotoval vsem nedemokratičnim, levim in desnim družbenopolitičnim opcijam, vključno z avtoritarnimi komunističnimi gibanji in strankami (Sperber, 2013; Šercar, 2014).

Marx je leta 1848 zapisal, da Francija zaseda Flandrijo, Loreno in Alzacijo, prej ali slej bo zasedla tudi Belgijo, Nemčija in Šlezijo s pravico civilizacije proti barbarstvu in s pravico napredka proti zastajanju ter da je ta pravica vredna več kot vsi sporazumi, ki ji nasprotujejo, saj gre za pravico do zgodovinskega razvoja (Paul, 1981).

Engels (1849) piše, da so Južni Slovani v Avstriji, ki so proizvod tisočletnega zmedenega razvoja, tisto, kar so bili na Škotskem Galci, ki so podpirali Stuarte od 1640 od 1745, Bretonci v Franciji, ki so podpirali Burbone od 1792 do 1800, Baski v Španiji (v karlistični vojni v Španiji med konservativci in liberalci od 1834 do 1839, skupaj z Navarčani in Katalonci, op. avt.), ki so podpirali konservativnega protikralja Dona Carlosa (Orožen, 1933).

Po Engelsu so nosilci napredka v Avstriji le trije narodi, ki so ohranili svojo vitalnost in igrajo aktivno vlogo v zgodovini. To so Germani, Poljaki in Madžari. Iz teh razlogov so zdaj revolucionarni. Usoda drugih ras in narodov - velikih in majhnih - je, da propadejo $v$ revolucionarnem holokavstu. Južni Slovani, predvsem Hrvati, so leta 1848 izkazali svoj reakcionarni značaj. East (1944) kot predstavnik znanstvenega zgodovinskega zemljepisa je ugotovil, da gre v primeru Južnih Slovanov v srednji Evropi v času Karolinškega cesarstva v 9. stoletju za sorazmerno nazadnjaški narod. Po J. H. (Josip Horvat?) (1944) je gorski značaj nove 
domovine Hrvatov, ki so prišli v ta del Evrope v 7. stoletju, oblikoval njihovo nagnjenost $h$ konservativizmu in ohranjevanju preživelih družbenih razmer.

Engels (1849) se sprašuje, kdo je izvedel avstrijsko revolucijo: Dunaj ali Praga? Budimpešta ali Zagreb? Nemci in Madžari ali Slovani? Imperializem, kolonializem in hegemonija nad majhnimi slovanskimi narodi »brez zgodovine in vitalnosti za samostojno življenje» so v interesu napredka in civilizacije.

Zgodovina je dala bolj prav Herderju in njegovi teoriji kot »prerokbam« Marxa in Engelsa.

Za narod in državo je pomembna predvsem prihodnost. Narod, ki ima prihodnost, nikdar ne misli, da je dosegel vse cilje; če misli, da jih je, je to znak, da mu je usahnil živi vrelec lastne sile in da je obsojen na pogubo. (Riezler, 1913, cit. po Mohorič, 1915)

Teza o narodih «brez zgodovine« razkriva, da so osnova za ekstremni rasizem teorije o kulturnih razlikah in oznakah za te razlike (saj so težje in pomembnejše kot biološke), ne pa biološke teorije, in ni slučajno, da Huntington (1993) svojo teorijo o spopadu med civilizacijami utemeljuje z nespremenljivostjo razlik v zgodovini, jeziku, tradiciji in veri.

\subsection{Doba genoma}

Konec 20. stoletja se je začela doba genoma. Na področju raziskav populacijske genetike in antropologije sta se začela dva projekta: projekt Human Genome Diversity Project (HGDP) v ZDA in projekt Human Genome Organisation (HUGO) v Veliki Britaniji. Njun namen je priti do medicinskih in znanstvenih odgovorov na mitična vprašanja o izvoru ras in o razlikah med narodi ter o dedovanju tveganj za bolezni (Reardon, 2001). Projekt HGDP temelji na zastarelem pojmovanju ras, v raziskavah se uporablja tehnologija 21. stoletja za biologijo 19. stoletja (Orešković, 1995), o kateri je beseda v tem prikazu.

Izkazalo se je, da so razlike oziroma variacije med populacijami zelo majhne $(0,1-0,3)$ - manjše kot razlike znotraj populacij. Od 99,7 do 99,9 \% vseh 60 do 70 tisoč genov, kolikor jih je v človeku, je identičnih pri črncih, belcih, predstavnikih rdeče rase, aboriginih, pigmejcih, razlike pa se pojavljajo $v$ nekodiranih sekvencah gena, ki ne povzročajo nobenih fizičnih učinkov (Orešković, 1995).

\section{Sklepna misel}

Dejstvo je, da sta Trémaux in njegovo delo slabo znana. Trémauxa ni v nobeni standardni zgodovini biologije (Wilkins in Nelson 2008). Geslo o Trémauxu v angleški Wikipediji je imelo do pred kratkim samo dve vrstici (nekaj bolje je bilo v francoski različici). Francoska akademija znanosti je zavrnila Trémauxevo delo, verjetno zaradi uporabe Darwinove teorije evolucije za ljudi. Francoski biologi Darwinovih idej niso sprejeli v celoti. Darwin je že sam uvidel, da večina problemov na področju svetovnega nazora, ki jih je povzročilo njegovo delo, izhaja iz ideje o človeški evoluciji. To je bilo eno od glavnih področij, pri katerem se Darwin in Alfred Russel Wallace (1823-1913), ki je samostojno razvil zamisel o naravni selekciji, nista strinjala, saj Wallace te ideje ni uporabil za ljudi.

Pregledovanje literature je neločljiv del raziskovalnega dela. Zgodba o Pierru Trémauxu ponazarja, kako dejstva, kot so potegavščine, novinarske race, neresnične pripovedi, miti in predsodki, ki ne spadajo $v$ znanost, težave pri dojemanju in sprejemanju novih znanstvenih paradigem ter tudi počasno in geografsko omejeno širjenje znanstvenih spoznanj in 
posledična neinformiranost o znanstvenih odkritjih drugje po svetu, škodijo ekologiji znanstvenega komuniciranja in informiranja. Iz napačnih podatkov ne moremo organizirati informacij, prav tako tudi ne znanja iz lažnih informacij. Za Pierra Trémauxa je malokdo slišal. J. S. Wilkins in G. J. Nelson sta pokazala, da si Trémaux zasluži ugled teoretičnega biologa. Poleg Trémauxa so udeleženci zgodbe še številni drugi znanstveniki in misleci, predvsem Moritz Wagner, Charles Darwin, Karl Marx, Friedrich Engels in Stephen Jay Gould. Trémaux je v knjigi iz leta 1865 prehitel teorijo prekinjenega ravnotežja Goulda in Eldredgea za več kot stoletje. Prvi je objavil filogenetsko drevo $v$ obliki, $v$ kateri ga poznamo danes. Prehitel je idejo alopatrične speciacije Moritza Wagnerja za 3 leta, vendar ga Wagner ne omenja, Darwin pa citira Wagnerja, in ne Trémauxa. Trémaux je uporabil Darwinovo teorijo evolucije za razvoj človeka 6 let, preden je to storil Darwin. Malo ljudi je prebralo Trémauxevo knjigo. Namesto tega so se zanašali na dopisovanje med Karlom Marxom, ki je mislil, da je knjiga imenitna, in Friedrichom Engelsom, ki je menil, da je knjiga slaba. Veliko zmede je nastalo zaradi prevajanja francoske besede sol, ki jo uporablja Trémaux, v angleščino z besedo soil (zemlja) v pomenu prst, in ne habitat (življenjski prostor), kar je pripeljalo do sklepa, da Trémaux trdi, da je kakovost tal tista, ki predvsem vpliva na evolucijo. Gould je zapisal, da nikoli ni srečal bolj absurdne trditve.

Na spoznanju geografske izolacije je Trémaux zgradil geološko teorijo, po kateri evolucijo nacij in ras določa geološki razvoj Zemlje. Po Darwinu je napredek naključje, po Trémauxu nuja. Višje civilizacije, narodi in rase nastajajo na boljših zemljiščih. Marx je razvil socialno razlago, vendar se je pod vplivom "geološkega« rasizma Pierra Trémauxa odmikal v smeri nacionalizma, kolonializma in rasizma predvsem $v$ odnosu do Slovanov, podobno tudi Engels. Poleg geološke in socialne teorije obstajata še kulturna in biološka razlaga razlik med človeškimi populacijami. Raziskave genoma so pokazale, da so razlike med populacijami zelo majhne $(0,1-0,3)$, manjše kot razlike med posamezniki znotraj populacij. Rasizem ni pogojen z genetskimi razlikami, temveč s kulturnimi teorijami pri tolmačenju teh razlik. Kulturne razlike in oznake za te razlike so pomembnejše kot biološke, in ni naključje, da teorije o spopadu med civilizacijami temeljijo na nespremenljivosti razlik v zgodovini, jeziku, tradiciji in veri, ne pa na bioloških razlikah. Kakor koli že, rasne teorije so ne glede na vrsto razlage sofisticirano ideološko sredstvo za opravičevanje hegemonije, imperializma in kolonializma, šovinizma, nacionalizma in diskriminacije skupin in posameznikov ter drugih oblik krivičnega svetovnega reda med narodi in posamezniki v preteklosti, sedanjosti in prihodnosti.

Človeška vrsta je kakih 99 odstotkov evolucijske izkušnje doživela v Afriki (McClellan, Lehner in King, 2017). Pod kožo smo vsi Afričani in rasistično izključevanje Afričanov iz raziskav genoma za namene ugotavljanja tveganja za bolezni pri tovrstnih znanstvenih raziskavah ni upravičeno, če si želimo, da bi bile te raziskave uspešne. Genetika afriških populacij razkriva manjkajočo plast človeških variacij, ki so nastale pred 100.000 do 5 milijoni let. Ogromno število starodavnih variacij in selektivni pritiski, ki so jih afriške populacije preživele, dajejo vpogled $v$ gene, ki so odgovorni tudi za zapletene lastnosti vseh drugih človeških populacij drugje po svetu. 


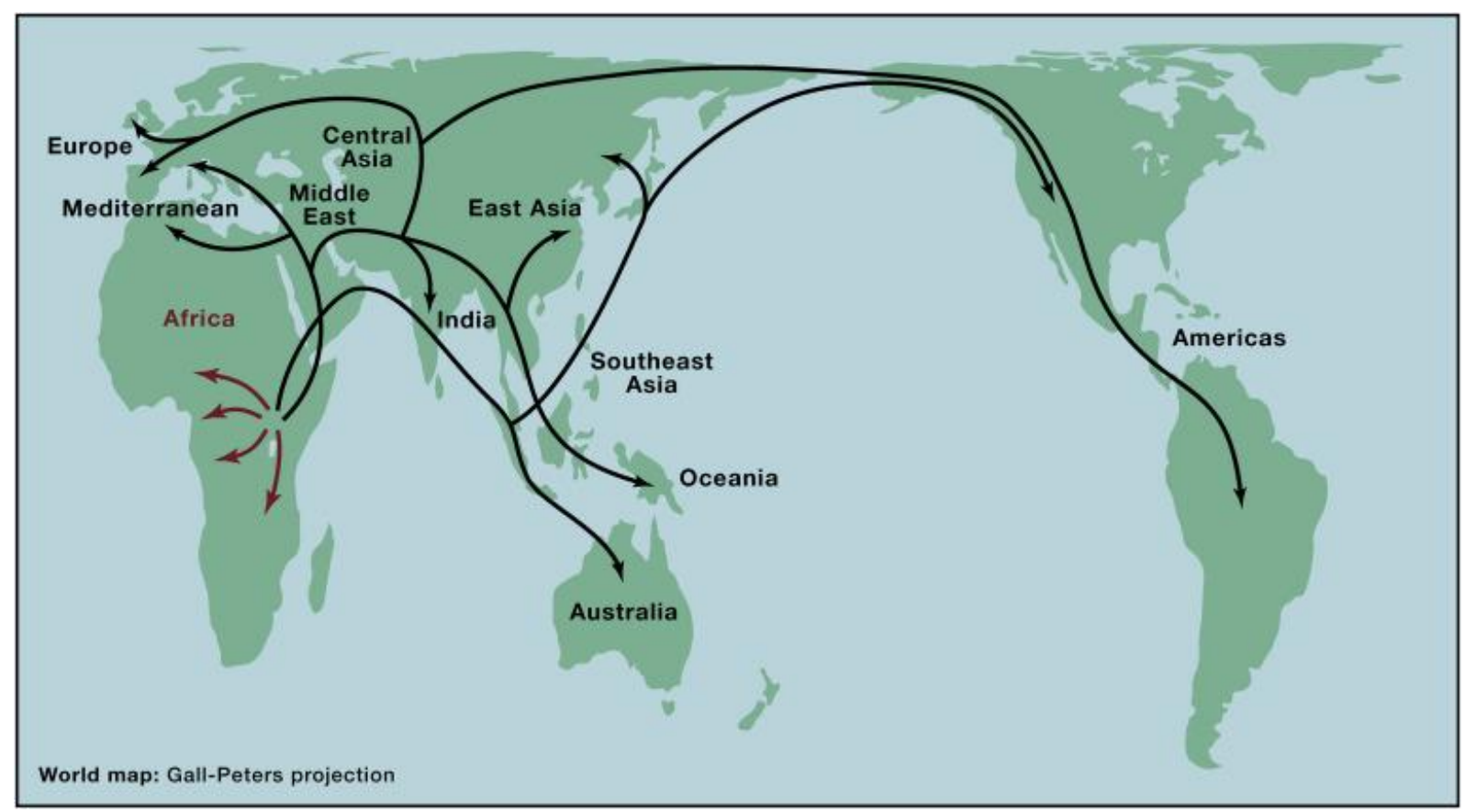

Slika 7: Človeške migracije. Ljudje in šimpanzi v Afriki so se razšli pred 5 do 6 milijoni let. Migracije majhnih skupin ljudi iz Afrike so se začele pred manj kot 100.000 leti. Genetika afriških populacij kaže razlike, ki so se medtem razvile.

Eric Turkheimer, psiholog na Univerzi v Virginiji, na svojem blogu Gloomy Prospect pravi, da bo posledica nekritičnega sprejemanja rezultatov raziskav na področju genetike uvajanje »resnično grozljivih socialnih politik«. Najslabša mogoča posledica bo biološko deterministična rasna diskriminacija, naravnana na posameznika. Poligenske ocene tveganja so tako nepoštene, kot je nepošteno napovedovanje našega inteligenčnega količnika na podlagi inteligenčnega količnika bratranca, ki ga nismo nikoli srečali (Regalado, 2018).

Toda etična nesprejemljivost teh posledic ne bo ustavila hitrega razvoja genetskih raziskav (Turkheimer, 2017). Do lanskega leta nobena genska različica ni bila nikoli povezana neposredno z rezultati testa inteligenčnega količnika. Od takrat so študije, ki so vključevale več kot 300.000 ljudi, povezovale 206 genskih različic z inteligenco. To pomeni, da lahko genetski rezultati zdaj napovedo uspešnost osebe pri inteligenčnem testu v višini $10 \%$. Ko bo zbranih več podatkov, bi lahko dosegli 25 odstotkov. Ameriško podjetje Genomic Prediction namerava celo preizkusiti inteligenco zarodkov, da bi lahko starši zavrgli tiste, za katere se pričakuje, da so mentalno neprimerni, kar frapantno spominja na nacistično »rasno higieno" (evgeniko) z eksterminacijo manjvrednih nacij in ras. ${ }^{12}$

\footnotetext{
12 Rasizem ima moč preoblikovanja tako desnice kot levice (Resnikoff, 2017). O nacionalnih interesih, ki so nad posameznimi političnimi interesi, naj bi obstajal konsenz. Ta konsenz predstavlja vsebino ideologije rasističnega nacionalizma. Zahodna liberalna demokracija in globalni tehnokratski neoliberalizem v gospodarstvu kot zadnja oblika upravljanja družbe in konec ideološkega razvoja človeštva (Fukuyama, 1992) sta danes v veliki nevarnosti pred naletom nove oblike fašizma, ki se je pojavil v obdobju oživitve neofašizma (Berlet, 2016). Deli Berletovega prispevka so se najprej pojavili na spletni strani PRA (Political Research Associates) v poglavju z naslovom Too Close for Comfort (Preblizu za udobje) z drugimi študijami, ki so bile kasneje vključene v knjigo o desnemu populizmu v ZDA (Berlet in Lyons, 2000). Istega leta (1992), ko je bila objavljena Fukuyamova knjiga, je na predsedniških volitvah v ZDA zmagal Bill Clinton, ki je uresničil »postideološki zakon« med kapitalizmom kot filozofijo gospodarske rasti in zmernim socialnim liberalizmom. $V$ zadnjih nekaj letih 20. stoletja se je pojavila nova oblika fašizma, poimenovana tretji politični red (angl. Third Position), ki si prizadeva strmoglaviti sedanje vlade in jih nadomestiti z
} 
Distopija, sumljiva medicina ali preboj v preprečevanju bolezni? Genomska napoved je lahko vse troje. Jasno je, da je bilo zaradi podatkov, potrebnih za napovedovanje, ki postajajo prosto dostopni na spletu, leto 2018 prelomno za napovedovanje na osnovi DNK (Turkheimer, 2017).

Rasizem ni pogojen z genetskimi razlikami, temveč s kulturnimi teorijami pri tolmačenju teh razlik oziroma variacij.

Z metodološkega vidika naj bi bil glavni izsledek tega prikaza domneva, da so rasne teorije sofisticirano ideološko sredstvo za opravičevanje hegemonije, imperializma in kolonializma, nacionalizma in diskriminacije skupin in posameznikov ter drugih oblik krivičnega svetovnega reda med narodi, rasami in posamezniki v preteklosti, sedanjosti in prihodnosti, $v$ smislu, da so določene nacije, rase in posamezniki boljši kot drugi, namesto da bi prispevale $k$ pojasnjevanju razlik med njimi brez kakršnega koli vrednotenja.

\section{Reference}

Angus, I., 2018. Marx and Engels... and Darwin? The essential connection between historical materialism and natural selection. International Socialist Review, 65. Dostopno na:

https://isreview.org/issue/65/marx-and-engelsand-darwin [20. 6. 2019].

Anderson, B., 1991. Imagined communities. London: Verso.

Auden, W. H., 1940. Another time. New York: Academy of American Poets. Dostopno na: https://www.poets.org/poetsorg/poem/memory-sigmund-freud [20.6. 2019].

Bacon, F., 2011. Nova Atlantida. Ljubljana: Atelje za grafiko.

Bašić, N., 1991. V. S. Karadžić između jezikoslovlja i politike. Zagreb, Školske novine.

Bauer, B., 1843. Die Judenfrage. Braunschweig: Otto.

Behschnitt, W. D., 1992. O tipologiji nacionalizma u Srba i Hrvata. Časopis za suvremenu povijest, 24(3), str. 227-240.

Bell, D., 1972. The cultural contradictions of capitalism. Journal of Aesthetic Education, 6(1/2), str. 11-38. Dostopno na:

http://www.forschungsnetzwerk.at/downloadpub/bellculturalcontradictions.pdf [20. 6. 2019].

Berlet, C., 2016. What is the third position? Political Research Associates, December 16. Dostopno na: https://www.politicalresearch.org/2016/12/19/what-third-position [20. 6. 2019].

monokulturnimi nacionalnimi državami, zgrajenimi okoli ideje prevlade rasnega nacionalizma in/ali prevlade verskega nacionalizma. Neofašisti tretjega političnega reda so že organizirani v ZDA, Evropi in na Bližnjem vzhodu. Tretji politični red v Evropi imenujejo Nova desnica. Skupine tretjega političnega reda verjamejo v rasno homogeno decentralizirano plemensko obliko nacionalizma in so prepričani, da so razvili ideologijo, ki je onkraj tako komunizma kot kapitalizma. Privrženci tretjega političnega reda v ZDA predstavljajo rasistično gibanje belih delavcev, farmarjev in revežev, ki še naprej iščejo nove člane na levici in predstavljajo nadaljevanje Strasserjevega krila nemškega nacionalnega socializma (nacizma), kritičnega do Hitlerjeve različice nacizma, ki je izneverila delavski razred (Berlet, 2016). 
Berlet, C. in Lyons, M. N., 2000. Right-wing populism in America: too close for comfort. New York: Guilford Press.

Blumenbach, J., 1795. On the natural varieties of mankind. London: Longman and Green.

Brent, R. in Bruck, J., 2006. Can computers help to explain biology? Nature, 23 March, str. 416-417.

Campa, R., 2008. Making science by serendipity. A review of Robert K. Merton and Elinor Barber's The travels and adventures of serendipity. Journal of Evolution \& Technology, 17(1). Dostopno na: http://jetpress.org/v17/campa.pdf [20. 6. 2019].

Darwin, C. R., 1859. The origin of species by means of natural selection, or The preservation of favoured races in the struggle for life. London: John Murray. Dostopno na: http://darwinonline.org.uk/converted/pdf/1861 OriginNY F382.pdf [20. 6. 2019].

Darwin, C. R. 1861. On the origin of species by means of natural selection, or The preservation of favoured races in the struggle for life. 3rd ed. London: John Murray. Dostopno na: http://darwinonline.org.uk/content/frameset?itemID=F381\&viewtype=text\&pageseq=1 [20. 6. 2019].

Darwin, C. R., 1866. On the origin of species by means of natural selection, or The preservation of favoured races in the struggle for life. 4th ed. London: John Murray. Dostopno na: http://darwinonline.org.uk/content/frameset?pageseq=1\&itemID=F385\&viewtype=text [20. 6. 2019].

Darwin Online, 2016. Dostopno na: http://darwinonline.org.uk/EditorialIntroductions/vanWyhe notebooks.html [20. 6. 2019].

Dervin, B., 1983. Information as a user construct: the relevance of perceived information needs to synthesis and interpretation. V: Ward, S. A. in L. J. Reed, L. J. ur. Knowledge structure and use: implications for synthesis and interpretation. Philadelphia, PA: Temple University Press. Str. 153-183.

East, G., 1944. Poviestni zemljopis Evrope. Zagreb: Matica hrvatska.

Eldredge, N. in Gould, S. J., 1972. Punctuated equilibria: an alternative to phyletic gradualism. V: Schopf, T. J. M. ur. Models in paleobiology. San Francisco: Freeman Cooper. Str. 82-115.

Engels, F., 1849. Der magyarische Kampf. Neue Rheinische Zeitung, Nr. 194. Dostopno na: http://www.mlwerke.de/me/me06/me06 165.htm [20. 6. 2019].

Engler A., 1881. Über die morphologischen Verhältnisse und die geographische Verbreitung der Gattung Rhus, wie der mit ihr verwandten, lebenden und ausgestorbenen Anacardiaceae. Botanische Jahrbücher für Systematik, Pflanzengeschichte und Pflanzengeographie ${ }_{2}$ 1, str. 365-426. Dostopno na: http://www.biodiversitylibrary.org/title/60\#page/385/mode/1up [20. 6. 2019].

Friedman, B. M., 2006. The moral consequences of economic growth. Society, 43. Dostopno na: 
http://scholar.harvard.edu/files/bfriedman/files/the moral consequences of economic $\mathrm{gr}$ owth 0.pdf [20.6. 2019].

Fukuyama, F., 1992. The end of history and the last man. New York: Free Press.

Gellner, E., 1983. Nations and nationalism. Ithaca, NJ: Cornell University Press.

Goethe, J. W., 1823. Serbische Lieder. Dostopno na:

http://www.zeno.org/Literatur/M/Goethe,+Johann+Wolfgang/Theoretische+Schriften/Serbi sche+Lieder [20. 6. 2019].

Gould, S. J, in Eldredge, N., 1977. Punctuated equilibria: the tempo and mode of evolution reconsidered. Paleobiology, 3(2), str. 115-151.

Gould, S. J., 1997. Redrafting the tree of life. Proceedings of the American Philosophical Society, 141, str. 30-54. Dostopno na: http://www.jstor.org/stable/987248 [20. 6. 2019].

Gould, S. J., 1999a. Lyell's Pillars of Wisdom. (Charles Lyell) (includes from the works of Lyell, Pliny the Younger, Pliny the Elder, and Robert Frost). Natural History, April. Dostopno na: http://www.stephenjaygould.org/ctrl/archive/stephen jay gould/gould lyell's-pillars.html [20. 6. 2019].

Gould, S. J., 1999b. A Darwinian gentleman at Marx's funeral. Natural History, 108(7), str. 32-41.

Gould, S. J., 2002. The structure of evolutionary theory. Cambridge: Belknapp Press.

Hobsbawm, E., 1990. Nations and nationalism since 1780: programme, myth, reality. Cambridge: Cambridge University Press.

Hooton, E. A., 1955. The physical anthropology of Ireland. Cambridge: Harvard University Museum Papers.

Huntington, S. P., 1993. The clash of civilizations? Foreign Affairs, 72(3), str. 22-49.

Huxley, T. H., 1863. Evidence as to man's place in nature. London: Williams \& Norwood. Dostopno na: http://www.gutenberg.org/files/2931/2931-h/2931-h.htm [22. 7. 2019].

Isaacs, H., 1975. Idols of the tribe: group identity and political change. Cambridge, MA: Harvard University Press.

J. H. (Josip Horvat?), 1944. Umetak. V East, G. ur. Poviestni zemljopis Evrope. Zagreb: Matica hrvatska. Str. A-G.

Kuznets, S., 1971. Modern economic growth: findings and reflections. Prize lecture. Dostopno na: https://www.nobelprize.org/nobel prizes/economic-sciences/laureates/1971/kuznetslecture.html [22. 7. 2019].

Latour, B., 1998. On actor network theory: a few clarifications $1 / 2$. Nettime mailing list archives, January 14. Dostopno na: http://www.nettime.org/Lists-Archives/nettime-I9801/msg00019.html [11. 12. 2014]. 
Lukacs, G., 1986. Zgodovina in razredna zavest: študije o marksistični dialektiki. Ljubljana: Inštitut za marksistične študije ZRC SAZU.

Luthar, O., Šašel Kos, M., in Grošelj, N., 2006. Zgodovina historične misli: od Homerja do začetka 21. stoletja. Ljubljana: ZRC SAZU, Založba ZRC.

Marx, K., 1844. Zur Judenfrage. Geschrieben August bis Dezember 1843. Deutsch

Französische Jahrbücher. Dostopno na: https://www.staff.uni-

giessen.de/ g31130/PDF/marx/judenfrage [22. 7. 2019].

Marx, K., 1999. Capital, Vol. III, The process of capitalist production as a whole. New York: International Publishers. Dostopno na:

https://www.marxists.org/archive/marx/works/download/Marx Capital Vol 3.pdf [22. 7. 2019].

Marx, K. in Engels, F., 1853. Extracts from the New York Tribune on the Crimean War. V: Blackstock, P. in Hoselitz, B.: Karl Marx and Frederick Engels, The Russian menace to Europe. London: George Allen and Unwin, str. 121-202. Dostopno na:

https://www.marxists.org/archive/marx/works/subject/russia/crimean-war.htm [22. 7. 2019].

Marx, K., 1866. Letters to Dr. Kugelmann, Modena Villas, Maitland Park, Haverstock Hill, London. 39 October 9, 1866. Dostopno na:

http://ciml.250x.com/archive/marx engels/english/1934 marx letters to kugelmann.pdf [22. 7. 2019].

Marx, K. in Engels, F., 1961. Rani radovi. Zagreb: Naprijed.

Marx, K. in Engels, F. 1975. Marx-Engels collected works [MECW]. Vol. 40. Moscow: Progress Publishers.

Marx, K. in Engels, F. 1975a. Selected correspondence 1846-1895 [MESC]. New York: International Publishers.

Marx, K. in Engels, F. 1975b. Selected correspondence 1846-1895 [MESC]. New York: International Publishers.

McClellan, J. M., Lehner, T. in King, M. C., 2017. Gene discovery for complex traits: lessons from Africa. Cell, 171(2), str. 261-264. Dostopno na:

https://www.sciencedirect.com/science/article/pii/S0092867417311315 [22. 7. 2019].

Mendel, M., 1865. Experiments in plant hybridization. Read at the February 8th, and March 8th, 1865, meetings of the Brünn Natural History Society. Dostopno na:

http://www.esp.org/foundations/genetics/classical/gm-65.pdf [22. 7. 2019].

Mivart, St G.,1865. Contributions towards a more complete knowledge of the axial skeleton in the primates. Proceedings of the Zoological Society of London, 33, str. 545-592.

Mohorič, J., 1915. O nacionalizmu in internacionalizmu. Čas: znanstvena revija »Leonove družbe«, 9(4), str. 177-185. Dostopno na: https://www.dlib.si/details/URN:NBN:SI:docMXN63EKY [22. 7. 2019]. 
Morgan, L . H., 1877. Ancient Society. Chicago.

Morrison, D., 2012a. Charles Darwin's unpublished tree sketches. The Genealogical World of Phylogenetic Networks, June 16. Dostopno na:

http://phylonetworks.blogspot.si/2012/06/charles-darwins-unpublished-tree.html [22. 7. 2019].

Morrison, D., 2012b. Who published the first phylogenetic tree? The Genealogical World of Phylogenetic Networks, August 13. Dostopno na:

http://phylonetworks.blogspot.si/2012/08/who-published-first-phylogenetic-tree.html [22. 7. 2019].

Morrison, D., 2013. Pierre Trémaux, unknown phylogeneticist. Dostopno na: http://phylonetworks.blogspot.si/2013/07/pierre-tremaux-unknown-phylogeneticist.html [22. 7. 2019].

Morrison, D., 2014. Is the tree of life the best metaphor, model, or heuristic for phylogenetics? Syst. Biol., 63(4), str. 628-638. Dostopno na:

http://sysbio.oxfordjournals.org/content/early/2014/04/21/sysbio.syu026 [22. 7. 2019].

Reardon, J. 2001. The Human Genome Diversity Project: a case study of science. Social Studies of Science, 31(3), str. 357-388. Dostopno na:

https://journals.sagepub.com/doi/pdf/10.1177/030631201031003002 [22. 7. 2019].

Orešković, S., 1995. Rasne varijacije ili rasne razlike: genetička produkcija novih rasnih mitova. So. ekol., 4(4), str. 331-343. Dostopno na: http://hrcak.srce.hr/141395 [22. 7. 2019].

Orožen, J., 1933. Zgodovina najnovejše dobe (1815-1920). Ljubljana: Merkur. Dostopno na: http://www.sistory.si/cdn/publikacije/11000/735/1933 Zgodovina najnovejse dobe za 8 razred srednjih sol.pdf [22. 7. 2019].

Pasture, P., 2015. Imagining European unity since 1000 AD. Basingstoke: Palgrave Macmillan. Paul, D., 1981. »In the interests of civilization «: Marxist views of race and culture in the Nineteenth Century. Journal of the History of Ideas, 42(1), str. 115-138. Dostopno na: http://www.dianebpaul.com/uploads/2/3/2/9/23295024/in the interests of civilization.pd f [22. 7. 2019].

Piketty, T., 2014. Capital in the Twenty-First Century. Cambridge: The Belknap Press. Dostopno na: http://dowbor.org/blog/wp-content/uploads/2014/06/14Thomas-Piketty.pdf [22. 7. 2019].

Regalado, A., 2018. Forecasts of genetic fate just got a lot more accurate. MIT Technology Review, February 21. Dostopno na:

https://www.technologyreview.com/s/610251/forecasts-of-genetic-fate-just-got-a-lotmore-accurate/ [22. 7. 2019].

Resnikoff, N., 2017. The Center has fallen, and white nationalism is filling the vacuum. ThinkProgress, January 5. Dostopno na: https://thinkprogress.org/the-center-has-fallen-andwhite-nationalism-is-filling-the-vacuum-beb0611dfe94\#.ygh7j2eop [22. 7. 2019]. 
Riezler, K., 1913. Die Erforderlichkeit des Unmöglichen, Prolegomena zu einer Theorie der Politik. München: G. Müller.

Saracevic, T. in Wood, J. B., 1981. Consolidation of information. Paris: General Information Programme and Unisist, Unesco.

Smith, A., 1991. National identity. Reno: University of Nevada Press. Ž

St. Thomas Aquinas, 1267a. The Summa Theologica (Translated by Fathers of the English Dominican Province), 1a, q. 75, a. 5, o. 4. Dostopno na:

http://www.documentacatholicaomnia.eu/03d/12251274, Thomas Aquinas, Summa Theologiae \%5B1\%5D, EN.pdf [25. 9. 2017].

St. Thomas Aquinas, 1267b. The Summa Theologica (Translated by Fathers of the English Dominican Province), 1a, q. 12, a. 4, o. 3. Dostopno na:

http://www.documentacatholicaomnia.eu/03d/12251274, Thomas Aquinas, Summa Theologiae \%5B1\%5D, EN.pdf [25. 9. 2017].

Sperber, J., 2013. Karl Marx: a nineteenth-century life. New York, London: Liveright publishing corporation. Dostopno na: http://www.amazon.com/Karl-Marx-A-NineteenthCentury-Life/[22. 7. 2019].

Steiner, G., 2011. Knjige koje nisam napisao. Zagreb: TIM.

Stendhal, H. B., 1932. Rdeče in črno: kronika leta 1830. Ljubljana: Tiskovna zadruga.

Šercar, T., 1988. Komunikacijska filozofija znanstvenih časopisa. Zagreb: Globus.

Šercar, T. M., 2007. Računalništvo, informacijska znanost in inženirstvo - zidaki nove znanstvene revolucije. Organizacija znanja, 12(1) , str. 10-16. Dostopno na:

https://www.cobiss.si/oz/HTML/OZ 20071 final/files/assets/common/downloads/OZ\%202 0071.pdf [22. 7. 2019].

Šercar, T. M., 2012. Plaidoyer za prenovljeno teorijo informacij. Organizacija znanja, 17(2), str. 61-74. Dostopno na: https://www.cobiss.si/oz/HTML/OZ 20122 final/24/ [22. 7. 2019].

Šercar, T. M., 2014. Svet na novi prelomnici - zabeležke ob branju knjig Capital in the Twenty-First Century Thomasa Pikettyja, The Entrepreneurial State Mariane Mazzucato in Karl Marx: a Nineteenth-Century life Jonathana Sperberja. Organizacija znanja, 19(2), str. 84-90. Dostopno na:

http://home.izum.si/cobiss/oz/HTML/Oz 20142 final/files/assets/common/downloads/pa ge0042.pdf [22. 7. 2019].

Škiljan, D., 1996. Leksikon antičkih autora. Zagreb: Latina \& Graeca, Matica hrvatska.

Trémaux, P., 1865. Origine et transformations de l'homme et des autres êtres. Paris: L. Hachette. Dostopno na:

https://books.google.si/books?id=qAFAAAAAIAAJ\&printsec=frontcover\&hl=sl\#v=onepage \&q \&f=false [25. 9. 2017]. 
Turkheimer, E., 2017. Origin of race differences in intelligence is not a scientific question. Gloomy prospect blog, June 2. Dostopno na:

http://www.geneticshumanagency.org/gha/origin-of-race-differences-in-intelligence-is-nota-scientific-question/[22. 7. 2019].

Wagner, M., 1873. The Darwinian theory and the law of the migration of organisms.

Dostopno na: http://www.ucl.ac.uk/taxome/lit/wagner/wagner\%201873.pdf [22. 7. 2019].

Weber, M., 2001. The protestant ethic and the spirit of capitalism. London, New York:

Routledge Classics. Dostopno na: https://www.ttu.ee/public/m/mart-

murdvee/EconPsy/1/Weber Max 1930-

2005 The Protestant Ethic and the Spirit of Capitalism.pdf [22. 7. 2019].

Wilkins J. S. in Nelson G. J., 2008. Trémaux on species: a theory of allopatric speciation (and punctuated equilibrium) before Wagner. History and Hhilosophy of the Life Sciences, 30, str. 179-206. Dostopno na: http://philsci-archive.pitt.edu/3806/1/Tremaux-on-species.pdf [22. 7. 2019]. 